Keynote Paper $2^{\text {nd }}$ Xiamen International Forum on Urban Environment

\title{
ZeroWasteWater: Short-cycling of Wastewater Resources for Sustainable Cities of the Future
}

Willy Verstraete* and Siegfried E. Vlaeminck

Laboratory of Microbial Ecology and Technology (LabMET), Ghent University, Coupure Links 653, 9000 Gent, Belgium (Email: Willy.Verstraete@UGent.be; Siegfried.Vlaeminck@UGent.be)

* Corresponding author

\begin{abstract}
Actual sewage treatment relies on conventional activated sludge (CAS), which reaches sufficiently low carbon, nitrogen and phosphorus effluent levels, but is not cost-effective, hardly achieves recovery, requires electricity equivalent to a fossil fuel consumption of $85 \mathrm{kWh}$ per inhabitant equivalent (IE) per year and has an operational $\mathrm{CO}_{2}$ footprint of $80 \mathrm{~kg} \mathrm{CO}_{2} \mathrm{IE}^{-1}$ year ${ }^{-1}$. Projected water and phosphorus shortages and the need to lower greenhouse gas emissions force us to rethink wastewater treatment for sustainable cities of the future. ZeroWasteWater offers an approach to short-cycle water, energy and valuable materials while adequately abating pathogens, heavy metals and trace organics. A less diluted waste stream will be obtained from sewerage improvements, a more rational use of potable water and the addition of ground kitchen waste, complemented by an advanced physicochemical or/and biological concentration step at the entry of the sewage treatment plant. Anaerobic digestion will recover electricity from the concentrated stream and further treatment will render a value of 6.2 EUR IE $^{-1}$ year $^{-1}$ under the form of the nutrients nitrogen and phosphorus, and the carbon-sequestrating biochar. In the water stream, residual nitrogen will be removed through partial nitritation and anammox, followed by heat recovery and add-on membrane technologies yielding potable water $\left(>65 \mathrm{~m}^{3} \mathrm{IE}^{-1}\right.$ year $\left.{ }^{-1}\right)$. Overall, compared to a CAS system without sludge digestion, the recovery of energy and nutrient in ZeroWasteWater avoids a fossil fuel use of $439 \mathrm{kWh} \mathrm{IE}^{-1}$ year $^{-1}$ and an operational emission of $88 \mathrm{~kg} \mathrm{CO}_{2} \mathrm{IE}^{-1}$ year ${ }^{-1}$. Interestingly, such approach is expected to be economically viable. The key challenges remain to incorporate water chain management in holistic urban planning and to render a cradle to cradle approach which society will find acceptable.
\end{abstract}

Keywords: greenhouse gas, microalgae, recovery, recycling, reuse, sustainability, OLAND, algal roof,...

\section{Conventional activated sludge (CAS): the wrong road}

Over the last decades, water technology has globally propagated the current concept of the human water cycle (Fig. 1.A). Water is harvested from a natural system, conditioned in a drinking water facility, transported to a buffer tank and then to the user where it is loaded with low levels of pollutants and heat energy. Subsequently, it is transported to a wastewater facility, treated in an energy-demanding dissipative way (total decomposition of all molecules) and returned to a natural system. Besides significant water losses along the way (up to $30-50 \%$ in Europe), this safe and precious drinking water is mainly used as a transport vector and only a minor part (3\% in Europe) for nutritional purposes (UNEP, 2004). 


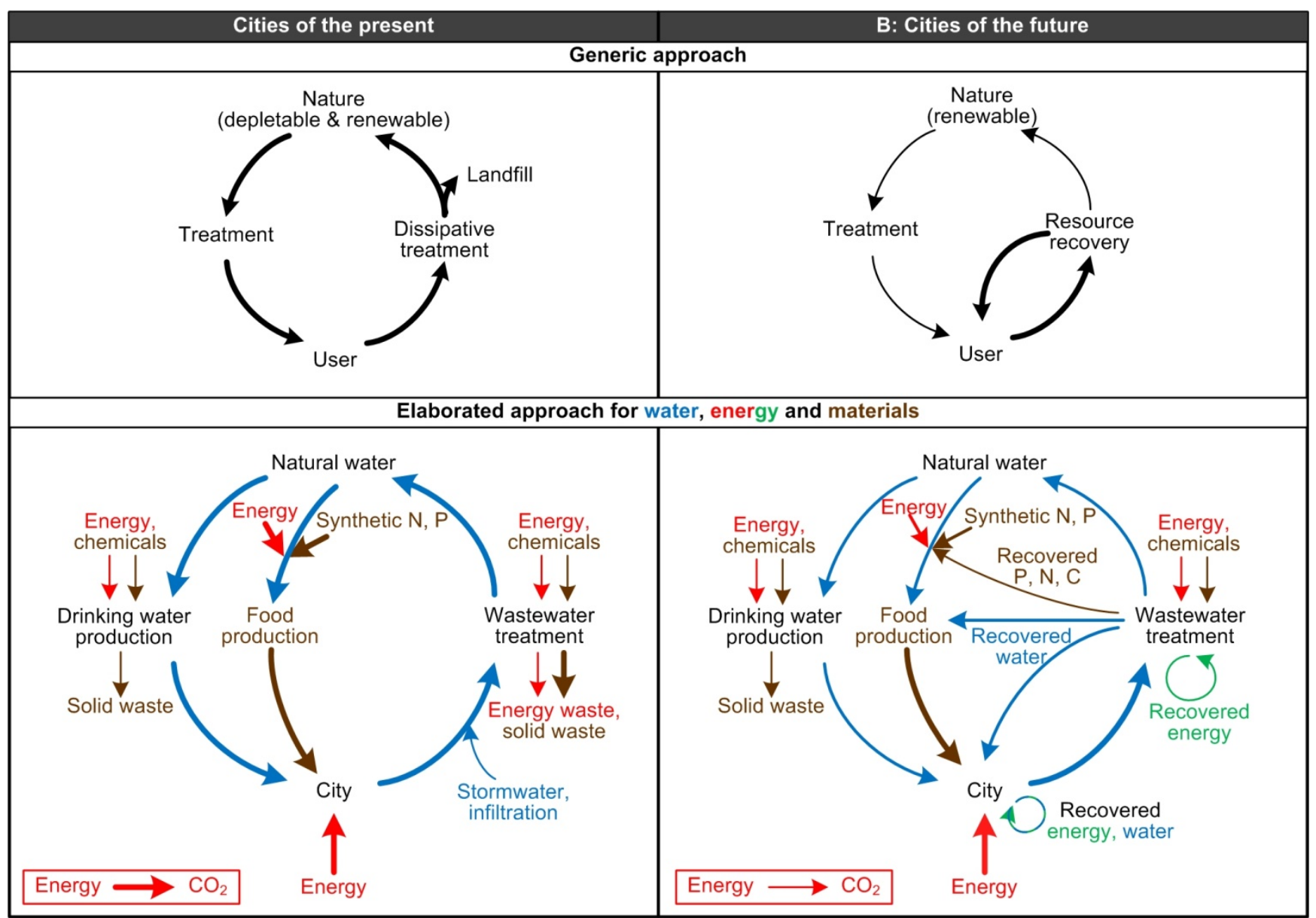

Figure 1. Major pathways in the cities of the present (A), wasting a lot of depletable resources, and in the cities of the future (B), rationally and sustainably recovering resources

The historical choice for bio-processes to deal with the clean-up of wastewater was based on the fact that microorganisms can bring about the 'insolubilization' of various pollutants which are dissolved in the water. A simple aeration permits bacterial cells to grow on the chemical oxygen demand (COD) present in excreted carbohydrates, lipids and proteins forming so-called sludge. In conventional activated sludge (CAS) systems, a low sludge-specific loading rate is applied, converting roughly half of the COD to sludge and half to $\mathrm{CO}_{2}$. The cleared water can be decanted from the sludge and is discharged to the environment, and the sludge is dewatered and disposed off. Although this concept for organic carbon removal was quite logical, it has evolved during the last decades to become increasingly complex, incorporating biological nutrient removal through nitrification/denitrification and enhanced biological phosphorus removal (Fig. 2). 


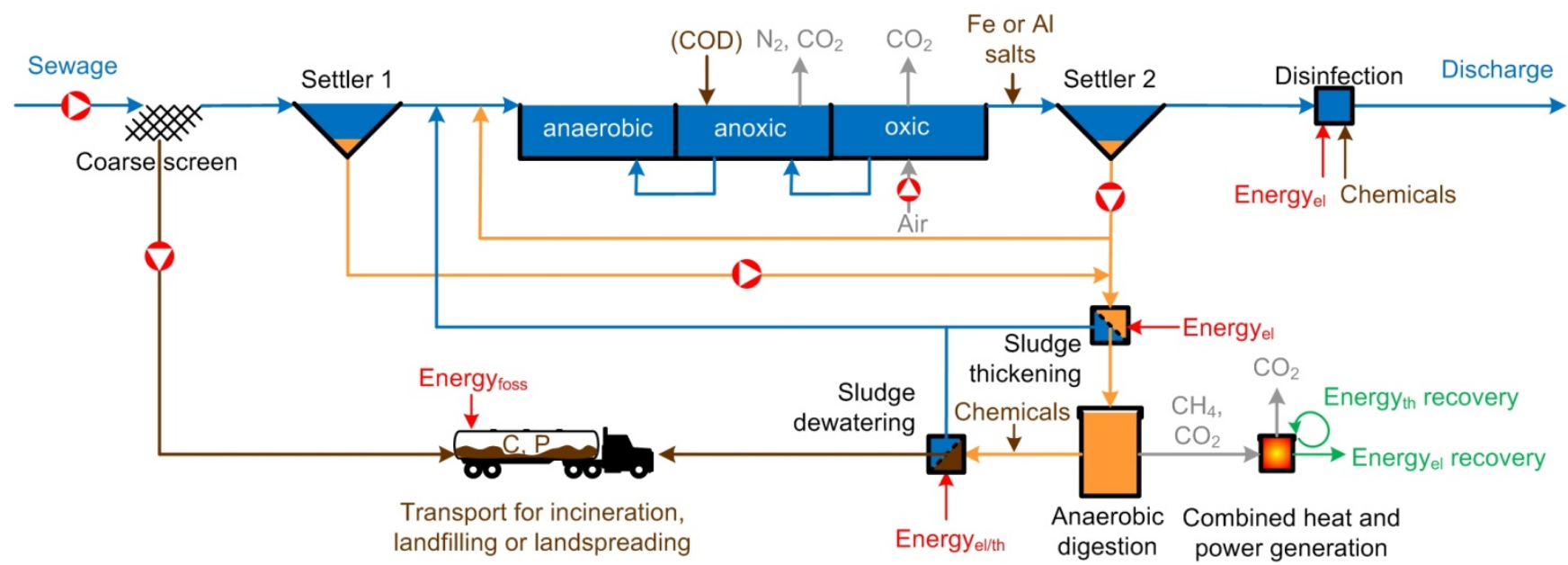

Figure 2. Major pathways for water, energy and materials in an advanced conventional activated sludge (CAS) sewage treatment plant with biological nutrient removal, sludge digestion and disinfection. Subscripts 'el', 'th' and 'foss' refer to electrical, thermal and fossil fuel, respectively.

A recent screening of 9 European countries along the Danube showed that CAS encompasses an overall cost (capital and operational expenditure) of about 17-30 EUR per inhabitant equivalent (IE) per year for large plants (> $100000 \mathrm{IE})$ and 30-40 EUR IE ${ }^{-1}$ year $^{-1}$ for smaller plants (10000-50000 IE) (Zessner et al., 2010). Of this budget, 30-38\% was for operational costs, of which sludge treatment and disposal accounted for up to $40 \%$. The latter is high since a lot of sludge is produced. In the EU27 for instance, around $10^{10} \mathrm{~kg}$ of sludge dry matter is produced yearly, representing around $20 \mathrm{~kg} \mathrm{IE}^{-1}$ year ${ }^{-1}$ (Milieu et al., 2008). An economic life cycle analysis showed that the CAS approach is, for most common plant sizes not the most cost-effective solution, mainly due to the high energy consumption and the high costs of qualified personnel (Tsagarakis et al., 2003).

In the context of energy efficiency, carbon footprint and recycling, the CAS approach is not sustainable. A screening of 343 treatment plants covering $30 \times 10^{6}$ IE in Nordrhein-Westfalen $(G)$ showed an overall electricity consumption of $33 \mathrm{kWh} \mathrm{IE}^{-1}$ year $^{-1}$, of which $20 \%$ was recovered from anaerobic sludge digestion (Müller and Kobel, 2004). Note that the net amount of electricity consumed corresponds to an equivalent fossil fuel demand of $85 \mathrm{kWh} \mathrm{IE}^{-1}$ year ${ }^{-1}$, given an average conversion of $0.31 \mathrm{kWh}$ electricity $\left(\mathrm{kWh}_{\mathrm{el}}\right)$ produced $\mathrm{kWh}^{-1}$ fossil fuel $\left(\mathrm{kWh}_{\text {foss }}\right)$ consumed (Maurer et al., 2003). Some very energy-efficient plants only require in the order of $20 \mathrm{kWh}_{\mathrm{el}} \mathrm{IE}^{-1} \mathrm{year}^{-1}$, of which around $50 \%$ is recovered by anaerobic sludge digestion (LFUW, 2001), but such plants are rather exceptional. In plants with and without anaerobic digestion, aeration constitutes over $60 \%$ and $70 \%$ of the energy consumption, respectively (Zessner et al., 2010). Although anaerobic digestion is the most sustainable approach for sludge stabilization (e.g. Suh and Rousseaux, 2002), the majority of the CAS sludge in Europe is not treated in this way, with some exceptions such as that of Sweden, where $83 \%$ of the sludge is digested (Lantz et al., 2007). With a $\mathrm{CO}_{2}$ emission of around $0.6 \mathrm{~kg} \mathrm{kWh}_{\mathrm{el}}{ }^{-1}$ in the EU25 (Fruergaard et al., 2009), the CAS $\mathrm{CO}_{2}$ footprint related only to net electricity consumption is $16 \mathrm{~kg} \mathrm{CO}_{2} \mathrm{IE}^{-1}$ year ${ }^{-1}$ in the example of the Nordrhein-Westfalen region. It should be noted that the electricity consumption from water and sludge treatment only represents $13 \%$ of the overall $\mathrm{CO}_{2}$ footprint, as additional direct emissions are generated from sewerage, water and sludge treatment, as well as indirect emissions from plant construction, production and transport of the used chemicals along with transport and disposal of the produced sludge (Clauwaert et al., 2010). As such, an overall sewage treatment $\mathrm{CO}_{2}$ footprint of $125 \mathrm{~kg} \mathrm{CO}_{2} \mathrm{IE}^{-1}$ year was calculated, with $64 \%$ or $80 \mathrm{~kg} \mathrm{CO}_{2} \mathrm{IE}^{-1}$ year $^{-1}$ represented by operational emissions. Besides the high environmental footprint of CAS, recovery of mineral nutrients is generally not considered. In the EU27 for example, the majority of the nitrogen is returned to the atmosphere and although most phosphorus is retained in the sludge, currently only $38 \%$ is recycled through landspreading (Milieu et al., 2008). Moreover, the $\mathrm{COD} / \mathrm{N} / \mathrm{P}$ ratio is often not high enough to bring about biological nutrient removal, 
requiring the addition of external COD, as exemplified by Isaacs \& Henze (1995), Dailey et al. (2010) and Fongsatitkul et al. (2008). This entails additional costs while simultaneously increasing the carbon footprint of wastewater treatment.

Besides the poor cost-effectiveness and the unsustainability of the current dissipative CAS approach, important societal problems force us to rethink and redesign the way we deal with water resources in the future. Strong contrasting changes in water availability and demand are expected for the upcoming decades, including predictions that by 2050 about half of the global population will face severe water shortage (Alcamo et al., 2007). On the one hand, the demand for water is rising due to an increase in population size (times 1.4: around 9.3 billion people by 2050), urbanization degree (times 1.9: around $70 \%$ by 2050), life standard and irrigation needs for food and fuel crops (UNEP and UN-HABITAT, 2010). On the other hand, the water availability may strongly decrease in some regions, whereas the rain pattern may show major shifts elsewhere, with subsequent periods of dramatic droughts and floods. By far the most unpredictable factor at present is the effect of future climate change. Anyhow, we must be vigilant of the upcoming changes and start planning to adapt to these in a sustainable way, thereby completely transversing the current lines of development in water technology. Although this might require major infrastructural works and management schemes, technological positivism should allow us to provide better sanitation to more people while consuming less energy and imposing a lower burden to the planet. The fact that sewage treatment still has to start from scratch in cities of the future, and also in many developing countries, offers an exquisite opportunity to directly choose for a more sustainable approach, not burdened with the historical installation of a rather linear water chain based on massive flushing and dissipative treatment.

\section{Sewage as a resource: why not?}

In earlier times, recovery from faecal matter and urine used to be practiced, be it not in a safe way. In the medieval time, cities were overridden with faecal matter and the inhabitants of the cities of the past were keen on re-utilising whatever was possible: faecal organics and mineral nutrients were used to grow vegetables in the local gardens and urine was used as a source of concentrated ammonia to treat textile fibres. What was not foreseen at that time was that each gram of faecal matter of a diseased person can contain several thousands of infectious propagules from viruses, bacteria, protozoa and helminths, of which contact with a few can already hamper human health. In the second half of the $19^{\text {th }}$ century, one realized about these concepts, and it was gradually introduced to flush excreta outside of the city without any short-cycling of its constituents. Additionally, more recent developments introduced trace organics (pharmaceuticals, personal care products and pesticides) and heavy metals in sewage water. However, wastewater remains plenty of valuable resources. In terms of sustainable development, these resources have to be short-cycled in a safe way in what we call the ZeroWasteWater approach (Fig. 1.B), minimizing waste from wastewater treatment. The pathways of the current water cycle will have to be downscaled significantly and 'wastewater' should be considered as 'used water', i.e. a resource to mine for energy, mineral plant nutrients (nitrogen and phosphorus), organic fertilizer and particularly water. Table 1 indicates the potential resources in used water representing a total value of about 80-85 EUR IE year $^{-1}$ under EU conditions, or about $1 \mathrm{EUR} \mathrm{m}^{-3}$ of treated water and hence, a considerable amount of money which is not recovered.

Table 1. Potential resource recovery from sewage and ground kitchen waste (KW) under European conditions in the ZeroWasteWater concept. Excreted loads of chemical oxygen demand (COD), N and P were taken from Henze (1997). Energy values refer either to electrical (el) or thermal (th) energy. IE: inhabitant equivalent; CHP: combined heat and power generation.

\begin{tabular}{lcccc}
\hline Resources in sewage and KW & $\begin{array}{c}\text { Production } \mathrm{IE}^{-1} \text { year }^{-1} \\
\text { Sewage }\end{array}$ & KW & Market price & \multicolumn{2}{c}{$\begin{array}{c}\text { Value }\left(\mathrm{EUR} \mathrm{IE}^{-1} \text { year }^{-1}\right) \\
\text { Sewage }\end{array}$} & Sewage $+\mathrm{KW}$ \\
\hline Water $^{\mathrm{a}}$ : sewage + storm/infiltration & $64+151 \mathrm{~m}^{3}$ & & & \\
Potable water $^{\mathrm{b}}$ & $54 \mathrm{~m}^{3}$ & $1.2 \mathrm{EUR} \mathrm{m}^{-3}$ & 65.4 & 65.4 \\
\hline
\end{tabular}




\begin{tabular}{|c|c|c|c|c|c|}
\hline $\begin{array}{l}\text { Heat recovery }\left(5^{\circ} \mathrm{C} \text { cooling }\right)^{\mathrm{c}} \\
\text { - Electricity consumption } \\
\text { - Heat recovered }\end{array}$ & $\begin{array}{l}-179 \mathrm{kWh}_{\mathrm{el}} \\
496 \mathrm{kWh}_{\mathrm{th}}\end{array}$ & & $\begin{array}{l}-0.10 \mathrm{EUR}_{\mathrm{kWh}} \mathrm{kWd}^{-1 \mathrm{~d}} \\
0.05 \mathrm{EUR}_{\mathrm{kWh}}^{-1 \mathrm{~d}}\end{array}$ & 6.9 & 6.9 \\
\hline$\overline{\text { Overall COD }} \mathrm{e}^{\mathrm{e}}$ & $47 \mathrm{~kg}$ & $33 \mathrm{~kg}$ & & & \\
\hline COD converted to biogas ${ }^{\mathrm{f}}$ & $27 \mathrm{~kg}$ & $18 \mathrm{~kg}$ & & & \\
\hline - Electricity from biogas CHP & $23 \mathrm{kWh}_{\mathrm{el}}$ & $16 \mathrm{kWh}_{\mathrm{el}}$ & $0.10 \mathrm{EUR} \mathrm{kWh}^{-1 \mathrm{~d}}$ & 2.3 & 3.9 \\
\hline - Heat from biogas CHP & $24 \mathrm{kWh}_{\mathrm{th}}$ & $17 \mathrm{kWh}_{\mathrm{th}}$ & $0.05 \mathrm{EUR} \mathrm{kWh}^{-1 \mathrm{~d}}$ & 1.2 & 2.0 \\
\hline COD in sludge from digestor ${ }^{g}$ & $11 \mathrm{~kg}$ & $7.9 \mathrm{~kg}$ & & & \\
\hline - COD converted to biochar ${ }^{\mathrm{h}}$ & $5.7 \mathrm{~kg}$ & $3.9 \mathrm{~kg}$ & $0.14 \mathrm{EUR} \mathrm{kg}^{-1} \mathrm{COD}$ & 0.8 & 1.3 \\
\hline Nitrogen & $4.7 \mathrm{~kg}$ & $0.4 \mathrm{~kg}$ & & & \\
\hline Recovered nitrogen ${ }^{\mathrm{i}}$ & $2.4 \mathrm{~kg}$ & $0.2 \mathrm{~kg}$ & 1.15 EUR kg ${ }^{-1} \mathrm{~N}$ & 2.7 & 2.9 \\
\hline Phosphorus & $0.91 \mathrm{~kg}$ & $0.73 \mathrm{~kg}$ & & & \\
\hline Recovered phosphorus ${ }^{j}$ & $0.82 \mathrm{~kg}$ & $0.66 \mathrm{~kg}$ & 1.35 EUR kg-1 $\mathrm{P}$ & 1.1 & 2.0 \\
\hline Overall & & & & 80.4 & 84.5 \\
\hline
\end{tabular}

${ }^{a}$ Since European household water consumption ranges from 85 to $265 \mathrm{~L} \mathrm{IE}^{-1} \mathrm{~d}^{-1}, 175 \mathrm{~L} \mathrm{IE}^{-1} \mathrm{~d}^{-1}\left(64 \mathrm{~m}^{3} \mathrm{IE}^{-1}\right.$ year $\left.{ }^{-1}\right)$ was chosen as a representative value (UNEP, 2004). Additionally, per $1 \mathrm{~L}$ of sewage, $1.18 \mathrm{~L}$ of storm water and $1.18 \mathrm{~L}$ of infiltration water reach the sewage treatment plant, under average German conditions (Brombach et al., 2005), yielding $587 \mathrm{~L} \mathrm{IE}^{-1} \mathrm{~d}^{-1}\left(215 \mathrm{~m}^{3}\right.$ $\mathrm{IE}^{-1}$ year $\left.^{-1}\right)$.

${ }^{\mathrm{b}}$ A projected future water load of $234 \mathrm{~L} \mathrm{IE}^{-1} \mathrm{~d}^{-1}\left(85 \mathrm{~m}^{3} \mathrm{IE}^{-1} \mathrm{year}^{-1}\right)$ was used, i.e. $25 \%$ less sewage water without storm water and with $50 \%$ decreased infiltration. Assuming a recovery of $85 \%$ with microfiltration/ultrafiltration and $75 \%$ with reverse osmosis. Prices for drinking water vary from 0.2 to $2.1 \mathrm{EUR} \mathrm{m}^{-3}$ (UNEP, 2004), so an intermediate value of $1.2 \mathrm{EUR} \mathrm{m}^{-3}$ was chosen.

${ }^{\mathrm{c}}$ Two sequential heat pumps were used with a coefficient of performance (COP) of $5 \mathrm{kWh}_{\text {th }}$ produced $\mathrm{kWh}_{\mathrm{el}}{ }^{-1}$ consumed, hence recovering overall $64 \%$ of the energy. A projected future water load was used as mentioned footnote ' $\mathrm{b}$ '.

${ }^{d}$ European feed-in-tariffs for electricity from biomass range from 0.038 to $0.224 \mathrm{EUR} \mathrm{kWh}_{\mathrm{el}}{ }^{-1}$ (Europe's Energy Portal, 2010), so a value of $0.10 \mathrm{EUR} \mathrm{kWh}_{\mathrm{el}}{ }^{-1}$ was chosen, and also used as electricity price. Heat was assumed to be half as valuable as electricity.

${ }^{\mathrm{e}}$ In sewage without kitchen waste, $130 \mathrm{~g} \mathrm{COD} \mathrm{IE}^{-1} \mathrm{~d}^{-1}$ is excreted and it is assumed that around $80 \%$ of the COD ends up in the concentrated line for anaerobic digestion, mainly by the advanced concentration step and with a minor sludge contribution from subsequent biological treatment.

${ }^{\mathrm{f}}$ Anaerobic digestion of primary and secondary sludge at $35^{\circ} \mathrm{C}$ converts around $50 \%$ of the COD into biogas (Wett et al., 2007; Siegrist et al., 2008), whereas digestion of black water and kitchen waste can remove up to $70-80 \%$ of the COD, even at $25^{\circ} \mathrm{C}$ (Kujawa-Roeleveld et al., 2005; Meulman et al., 2010), which is in the same order as the digestability of (flocculated) grey water (Elmitwalli and Otterpohl, 2007; Hernandez Leal et al., 2010). A 70\% COD conversion from mixed sources was therefore assumed to be feasible at $35^{\circ} \mathrm{C}$. Further, biogas is produced at $0.5 \mathrm{~m}^{3} \mathrm{~kg}^{-1} \mathrm{COD}$ removed, contains $65 \% \mathrm{CH}_{4}$ at an energetic value of $10 \mathrm{kWh} \mathrm{m}^{-3} \mathrm{CH}_{4}$ and its burning in a combined heat and power unit has thermal and electrical efficiencies of 40 and $38 \%$, respectively (Murphy et al., 2004; Wett et al., 2007).

${ }^{g}$ Around $30 \%$ of the organic matter fed to the digestor is expected to remain in the sludge fraction.

${ }^{\mathrm{h}}$ Following pyrolysis at around $600^{\circ} \mathrm{C}$, about $50 \%$ of the organic carbon is expected to remain present in the biochar (Lua et al., 2004). The value for this carbon was deduced from the price for actions to decrease $\mathrm{CO}_{2}$ emissions, which amount to 100 EUR ton $^{-1} \mathrm{CO}_{2}$ for a $80 \%$ decrease in greenhouse gas emissions by 2050 (IPCC, 2007). With $\mathrm{C}_{5} \mathrm{H}_{7} \mathrm{O}_{2} \mathrm{~N}$ as biomass formula, the sludge leaving the digester contains $2.67 \mathrm{~g} \mathrm{COD} \mathrm{g}^{-1} \mathrm{C}$, yielding an approximate biochar market value of $0.14 \mathrm{EUR} \mathrm{kg}^{-1} \mathrm{COD}$ processed.

${ }^{1}$ Assuming an overall $\mathrm{N}$ recovery of $50 \%$. Fertilizer prices for urea, ammonium nitrate and ammonium sulphate ranged up to 0.88 to $1.48 \mathrm{EUR} \mathrm{kg}^{-1} \mathrm{~N}$ mid 2008 (Apodaca, 2010).

${ }^{\mathrm{j}}$ Since about $90 \%$ of the P ends up in the sludge (Cornel and Schaum, 2009), this was assumed as recovery percentage. Fertilizer prices for triple superphosphate and diammonium phosphate in 2010 were 1.1 and $1.6 \mathrm{EUR} \mathrm{kg}^{-1} \mathrm{P}$, respectively (The World Bank, 2010).

The major value of used water is contained in the transport vector itself, even in the assumption of a $25 \%$ decrease water consumption per capita per day, the exclusion of storm water and a $50 \%$ decrease of water infiltration in the sewers (Table 1). The second highest market value of wastewater is its temperature. Indeed, households do not only load water with pollutants but also with heat energy. In the Flemish region (B) for instance, on average $3000 \mathrm{kWh}_{\text {foss }}$ house year $^{-1}$ is consumed for water heating (Eandis, 2007). This represents about $10 \%$ of the energy consumed, since an average household energy budget is 15000 $\mathrm{kWh}_{\text {foss }}$ and $5000 \mathrm{kWh}_{\mathrm{el}}$ house ${ }^{-1}$ year $^{-1}$, jointly representing about $31000 \mathrm{kWh}_{\text {foss }}$ house $\mathrm{year}^{-1}$. At the average Flemish household composition of $2.46 \mathrm{IE} \mathrm{house}^{-1}$ (Belgian Science Policy, 2009), $1220 \mathrm{kWh}_{\text {foss }}$ 
$\mathrm{IE}^{-1}$ year $^{-1}$ is spent to warm water. Several options with a heat exchanger and/or heat pump exist to recover this energy either at the household level, in the sewer, or from the effluent of a wastewater treatment plant (Wanner, 2009). To minimize fouling in the heat recovery equipment, to maintain high performance of rather temperature-sensitive biological processes and to harvest an additional temperature increase of about $1{ }^{\circ} \mathrm{C}$ due to sewage treatment (Wanner et al., 2005), heat recovery from the effluent seems most attractive. In Breda (NL), daily measurements of the sewage temperature over the period $1998-2010$ yielded $17^{\circ} \mathrm{C}$ as average and median, and 8 and $25^{\circ} \mathrm{C}$ as minimum and maximum temperatures, respectively (Mollen, oral communication). Similarly, the average sewage temperature at an Austrian wastewater treatment plant was $17^{\circ} \mathrm{C}$ (Wett et al., 2007). From such temperatures, traditional water-water heat pumps cannot deliver water of more than $60^{\circ} \mathrm{C}$, but the sequential use of two heat pumps could yield hot water at $90^{\circ} \mathrm{C}$ (Thornberg and Johansen, 2010). Harvesting $5^{\circ} \mathrm{C}$ with this sequential approach consumes $179 \mathrm{kWh}_{\mathrm{el}} \mathrm{IE}^{-1}$ year ${ }^{-1}$ for the heat pump while producing $496 \mathrm{kWh}$ of thermal energy $\left(\mathrm{kWh}_{\mathrm{th}}\right)$ $\mathrm{IE}^{-1}$ year $^{-1}$ (Table 1). If this energy is used to heat the buildings of the treatment plant and its surroundings, this considerably lowers the $\mathrm{CO}_{2}$ footprint. In the EU25, about 0.6 and $0.3 \mathrm{~kg} \mathrm{CO}_{2} \mathrm{kWh}^{-1}$ is emitted to produce electricity and heat, respectively (Fruergaard et al., 2009). Hence, an equivalent emission of $42 \mathrm{~kg} \mathrm{CO}_{2} \mathrm{IE}^{-1}$ year ${ }^{-1}$ would be saved.

The organic matter of sewage contains energy which can be recovered through anaerobic digestion with a combined heat and power (CHP) unit. The potential energy recovery can even be increased by $70 \%$ when adding ground kitchen waste, by using a grinder or disposer installed under the kitchen sink (Table 1). At an average family of $2.46 \mathrm{IE}$ house ${ }^{-1}$, such device consumes about $1.4 \mathrm{kWh}_{\mathrm{el}}$ and $0.67 \mathrm{~m}^{3} \mathrm{IE}^{-1}$ year $^{-1}$ (Karlberg and Norm, 1999). The thermal energy recovered from the biogas $\left(41 \mathrm{kWh}_{\mathrm{th}} \mathrm{IE}^{-1}\right.$ year $\left.{ }^{-1}\right)$ will be (partly) needed in practice to heat the digestor. However, the possible electricity recovery is a net gain and amounts to $39 \mathrm{kWh}_{\mathrm{el}} \mathrm{IE}^{-1}$ year ${ }^{-1}$, which is a factor 4 higher than the electricity recovery of the current advanced CAS plants equipped with anaerobic digestion (LFUW, 2001; Siegrist et al., 2008). This recovery prevents an additional avoided emission of $23 \mathrm{~kg} \mathrm{CO}_{2} \mathrm{IE}^{-1}$ year ${ }^{-1}$ to produce electricity from the regular sources.

The $\mathrm{CO}_{2}$ footprint can additionally be decreased by sequestering part of the residual organic carbon. It should be noted that direct $\mathrm{CO}_{2}$ emissions from the biological oxidation of sewage $\mathrm{COD}$, burning of biogas and incineration of sludge are not taken into account when calculating the $\mathrm{CO}_{2}$ equivalent footprint of sewage treatment, since this carbon is of 'young' biogenic origin (IPCC, 2007). In contrast, the sequestration of sewage carbon has a net negative $\mathrm{CO}_{2}$ footprint. This can be achieved with the production of biochar, a kind of charcoal obtained from pyrolysing biomass (Lehmann, 2007). In the ZeroWasteWater concept, biochar gives rise to a sequestration potential of $13 \mathrm{~kg} \mathrm{CO}_{2} \mathrm{IE}^{-1}$ year ${ }^{-1}$ for sewage with added kitchen waste, as calculated from the solids production after anaerobic digestion (Table 1) with the generic biomass formula $\mathrm{C}_{5} \mathrm{H}_{7} \mathrm{O}_{2} \mathrm{~N}$, yielding $2.67 \mathrm{~g} \mathrm{COD} \mathrm{g}^{-1} \mathrm{C}$.

Biological nitrogen removal represents a major part of the overall electrical energy demand. Excreted nitrogen in sewage is around $4.7 \mathrm{~kg} \mathrm{~N} \mathrm{IE}^{-1}$ year $^{-1}$ (Table 1) and if $65 \%$ of this nitrogen is oxidized through nitrification/denitrification in the biological CAS unit (Siegrist et al., 2008) requiring $2.3 \mathrm{kWh}_{\mathrm{el}} \mathrm{kg}^{-1} \mathrm{~N}$ for aeration (Mulder, 2003) and roughly 25\% of the overall pumping requirements for recirculation to denitrify (Kartal et al., 2010), an overall $8.9 \mathrm{kWh}_{\mathrm{el}} \mathrm{IE}^{-1}$ year ${ }^{-1}$ is consumed. Since the latter only covers electricity, it hence requires more than $1 \mathrm{EUR} \mathrm{IE}^{-1} \mathrm{year}^{-1}$ to remove this nitrogen. In contrast, if only $50 \%$ could be recovered, a market value of about 3 EUR IE $^{-1}$ year ${ }^{-1}$ could be obtained (Table 1). Recovery options for ammonium from water include instance ion exchange, struvite precipitation or stripping. A rough estimation shows that nitrogen recovery can present a significant resource at a global level. Recovery of $50 \%$ of the nitrogen in sewage and kitchen waste equals $2.6 \mathrm{~kg} \mathrm{~N} \mathrm{IE}^{-1}$ year $^{-1}$ (Table 1 ) or 18 million ton $\mathrm{N}_{\text {year }}{ }^{-1}$ at a global scale (6.9 billion IE). Current global fertilizer production occurs through the Haber-Bosch process and is in the order of 121 million ton $\mathrm{N}$ year ${ }^{-1}$ (Galloway et al., 2008), hence in 
this best-case scenario, recovery could cover about $15 \%$ of the current nitrogen demand. Although synthetic nitrogen fertilizer is made from a non-depletable source, i.e. atmospheric nitrogen gas $\left(\mathrm{N}_{2}\right)$, a future cyclical and hence more sustainable approach might be in favour of nitrogen recovery.

The amount of phosphorus excreted in sewage and kitchen waste is 0.9 and $0.7 \mathrm{~kg} \mathrm{P} \mathrm{IE}^{-1}$ year $^{-1}$, respectively (Table 1), which is in most cases precipitated or incorporated into sludge through biological and/or chemical reactions, and subsequently dumped in landfills either directly or after incineration (Cornel and Schaum, 2009). In contrast to the main resource for nitrogen fertilizer production, the resource for phosphorus fertilizer production, i.e. mineral phosphate rock, is expected to be depleted in the coming 50-100 years (Cordell et al., 2009). Hence, phosphorus fertilizer prices are strongly rising, and recovery will be a necessity, and can be achieved through land spreading of sludge or biochar from sludge, struvite precipitation (after $\mathrm{P}$ release) or recovery from sludge ashes (in case no iron salts were used for precipitation). A rough best-case estimation shows that phosphorus recovery can present a significant fertilizer source at a global level. Global phosphorus fertilizer production is about 14 million ton $\mathrm{P}$ year ${ }^{-1}$ and a $90 \%$ recovery of the phosphorus in sewage and kitchen waste from the global population (6.9 billion IE) would yield 7.6 million ton $\mathrm{P}_{\text {year }}{ }^{-1}$, which represents $55 \%$ of the current phosphorus demand.

\section{Safety first: no short-cycling of faecal pathogens, heavy metals and trace organics}

Until the $19^{\text {th }}$ century, European cities regularly suffered from major outbreaks of waterborne diseases such as typhoid fever (Salmonella typhi) and cholera (Vibrio cholerae). These outbreaks were decreased with the implementation of sewerage systems in these cities as exemplified by the inverse correlation in the period 1870-1915 between the number of houses connected to public sewers and typhoid fever mortality in Berlin (Kruse, 1962). Notwithstanding sewerage and basic sanitation, the provision of safe drinking water is also of predominant importance for human health, as demonstrated by the very high child mortality in countries lacking these provisions (Fig. 3). Currently, still 13\% of the global population or 884 million people have no access to safe sources of drinking water and even 39\% of the population or 2.6 billion people are not connected to improved sanitation (WHO-UNICEF, 2010). Poor hygiene and unsafe water are responsible for around $88 \%$ of all diarrheal incidents. The latter diseases are one of the main contributors to child mortality including $15 \%$ of child deaths under the age of five, killing 1.3 million children in 2008 (UN, 2010). Given these high numbers, the United Nations have put forward Millennium Development Goals to improve the 1990 'reference situation' by 2015 . These goals aim at halving the amount of people without sustainable access to safe water and basic sanitation (Target 7.C) and decreasing the under-five mortality by two thirds (Target 4.A). Although it is realistic to achieve the drinking water target, the progression towards the sanitation and child health targets is not happening fast enough (UN, 2010; WHO-UNICEF, 2010). 


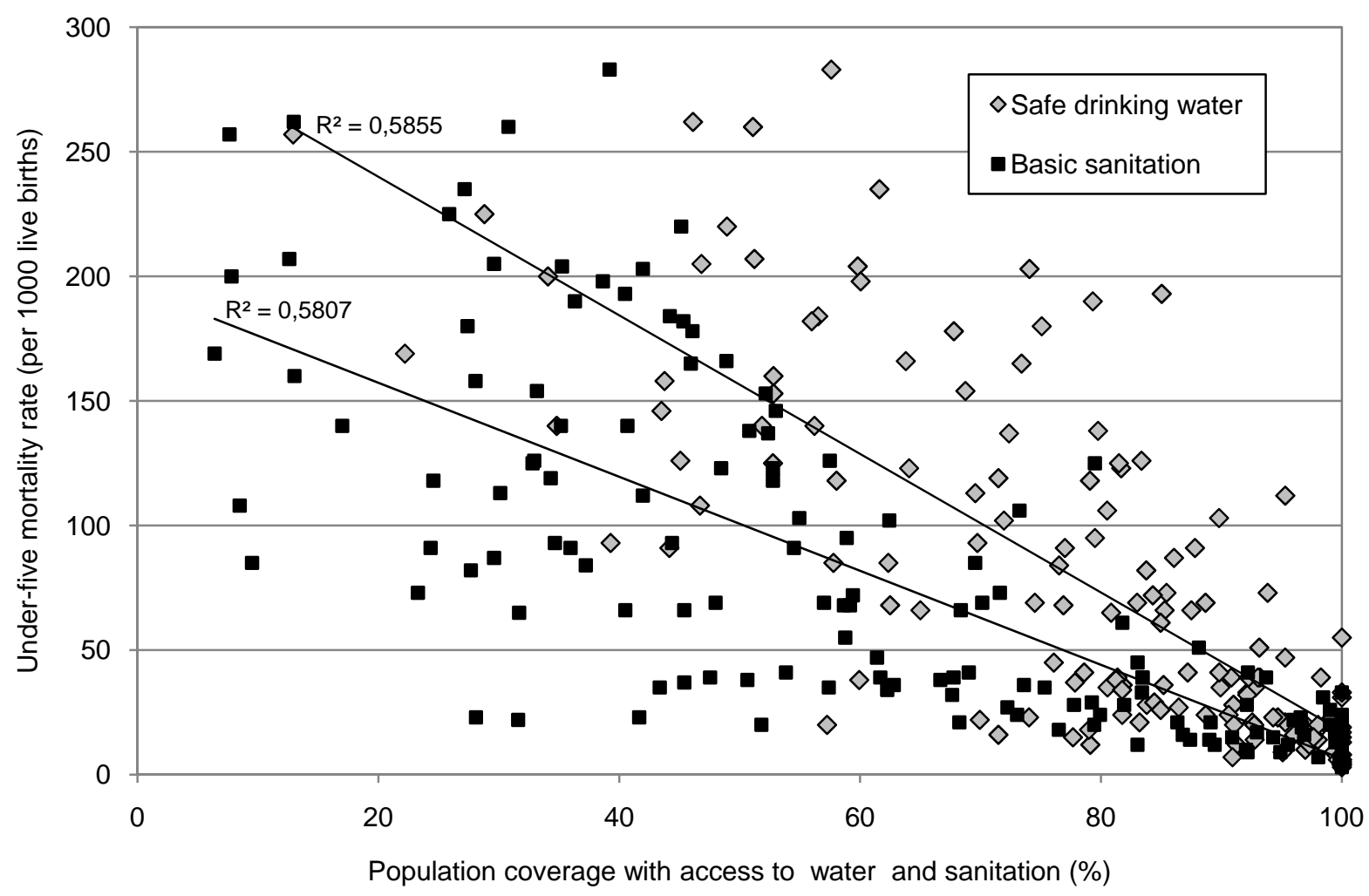

Figure 3. Inverse correlation between the mortality of young children (2003) and access to water and sanitation (2002), as shown tentatively with a linear regression. Data points represent 153 countries as obtained from WHO (2007).

Another risk when considering recovery is the short-cycling of bio-active trace organic compounds such as pharmaceuticals, personal care products and pesticides, which can be dealt with in an advanced treatment step (Bolong et al., 2009). Also the re-entry of heavy metals in the environment, food production or city has to be avoided. In Sweden for instance, the sources emitting or releasing these metals could be identified to a great extent for $\mathrm{Cu}, \mathrm{Zn}, \mathrm{Ni}$ and $\mathrm{Hg}$, whereas the origin of $\mathrm{Pb}, \mathrm{Cr}$ and $\mathrm{Cd}$ was less clear (Sorme and Lagerkvist, 2002). Hence, the entrance of some metals in the wastewater could partly be prevented, but care will have to be taken to remove other metals, for which various techniques are available (Kurniawan et al., 2006).

\section{Potable water recovery from sewage: feasibility proven}

In the city of Windhoek (Namibia), the conversion of wastewater to drinking water has been in place for 40 years (Haarhoff and Van der Merwe, 1996). Currently, the reclamation plant has a capacity of $7.5 \mathrm{Mm}^{3}$ year $^{-1}$ and its water constitutes about $25 \%$ of the city's potable water supply, in which CAS is followed by a multiple barrier series of reclamation processes: pre-ozonation, coagulation/flocculation, dissolved air flotation, dual media filtration, main ozonation, activated carbon filtration, ultrafiltration and chlorination (Lahnsteiner and Lempert, 2007). Reclamation costs in 2002 constituted of 0.25 and $0.38 \mathrm{EUR} \mathrm{m}^{-3}$ for investments and operation, respectively, yielding an overall cost of $0.63 \mathrm{EUR} \mathrm{m}^{-3}$, which was only $3 \%$ more expensive than water production from surface water (du Pisani, 2006). California experienced a closure of the water cycle with the 'Water Factory-21' concept, which has been functional from 1975 to 2004 and was succeeded by the 'Groundwater Replenishment System' from 2008 onwards (OCWD, 2009). This plant involves sequential microfiltration (MF), reverse osmosis (RO), and ultraviolet (UV) and $\mathrm{H}_{2} \mathrm{O}_{2}$ treatment and can produce up to $89 \mathrm{Mm}^{3}$ year ${ }^{-1}$, which is used to recharge a groundwater reservoir and prevent the intrusion of seawater therein. In this region, energy demand to reclaim wastewater is at least 50\% lower than import or other treatment options (Durham et al., 2001). Another example is the 
'NEWater' technology in Singapore, which treats secondary CAS effluent with MF/ultrafiltration (UF), RO and UV since 2003 (PUB, 2010). Currently, five facilities jointly produce around $138 \mathrm{Mm}^{3} \mathrm{year}^{-1}$, meeting $30 \%$ of Singapore's overall water needs, mostly directly used for non-potable industrial applications and only partly $(7.5 \%$ by 2011$)$ for indirect potable reuse through blending in a reservoir and subsequent drinking water treatment, constituting $2.5 \%$ of the city's potable water requirements.

In Koksijde (Belgium), a relatively small water cycle has been established since 2002 (Dewettinck et al., 2001; Van Houtte and Verbauwhede, 2008), but the high degree of water short-cycling in a non-arid climate renders this project unique from a sustainable point of view. In the period $2005-2009,40 \%$ of the secondary CAS effluent was further treated and the resultant water constituted $27 \%$ of the drinking water (Fig. 4). The tertiary treatment is based on UF ( $88 \%$ recovery) and RO (76\% recovery), but also includes dune infiltration to enable sustainable groundwater management of the dune aquifer. Energy consumption over the period 2005-2009 was on average 0.15 and $0.60 \mathrm{kWh}_{\mathrm{el}} \mathrm{m}^{-3}$ for UF and RO, respectively, and the overall from CAS effluent to drinking water was $0.54 \mathrm{EUR} \mathrm{m}^{-3}$, which was $25 \%$ cheaper than the additionally purchased potable water (IWVA, 2005, 2006, 2007, 2008, 2009; Van Houtte and Verbauwhede, 2010). The Hazard Analysis and Critical Control Points (HACCP) approach resulted in a stringent physicochemical monitoring strategy to guarantee the hygienic safety of the produced water (Dewettinck et al., 2001). The water complies with the microbiological standards for drinking water, i.e. the absence of the bacterial indicators Escherichia coli and enterococci, and furthermore contains none of the tested bacterial, protozoal and helminthic pathogens (Levantesi et al., 2010). Furthermore, none of the 96 tested pharmaceuticals and over 40 tested pesticides could be detected in a 2010 drinking water sample (Van Houtte, oral communication).

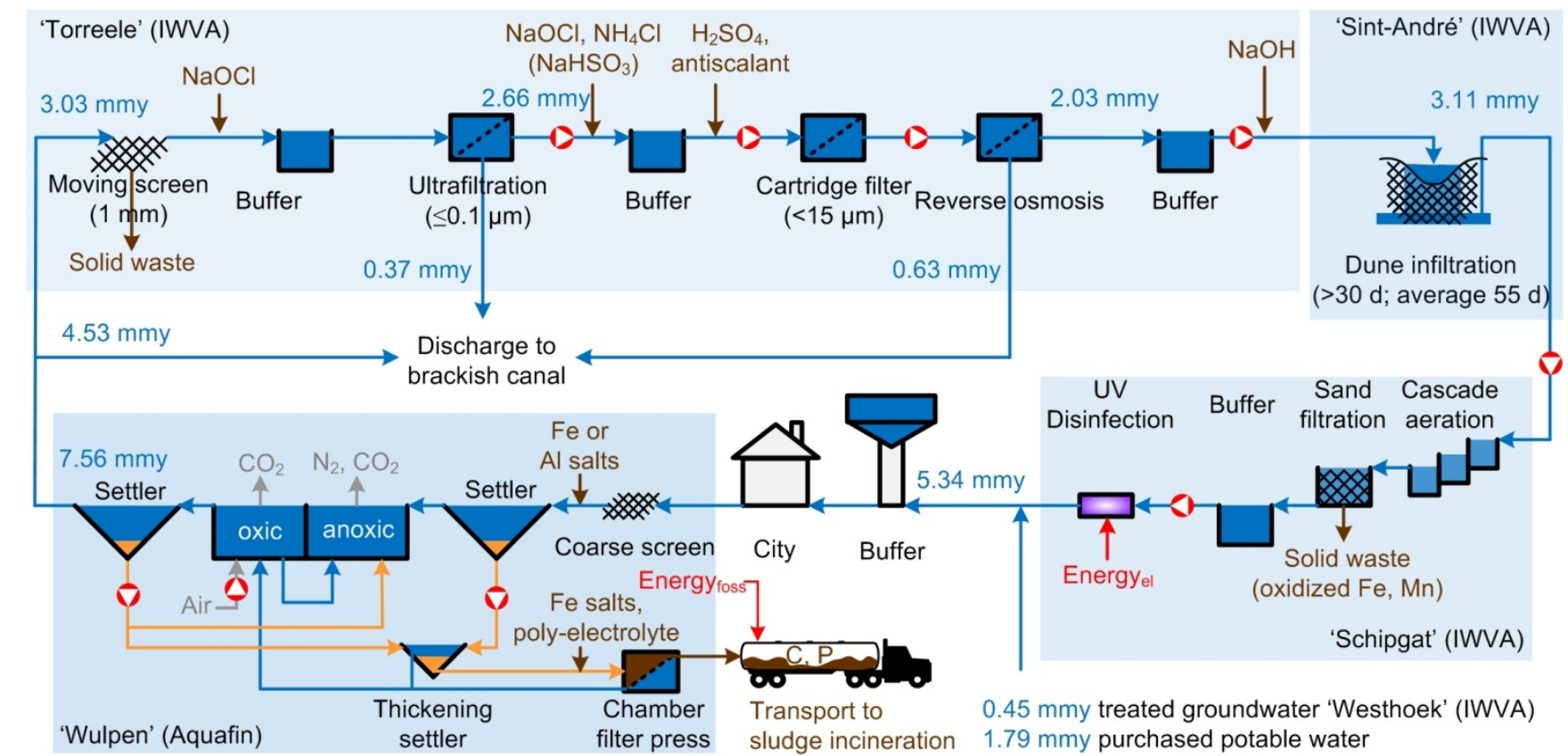

Figure 4. Scheme of wastewater reuse as practised in Koksijde (Belgium), with IWVA (Intercommunale Waterleidingsmaatschappij van Veurne-Ambacht) responsible for drinking water production and distribution and Aquafin for sewerage and wastewater treatment (Dewettinck et al., 2001; IWVA, 2005, 2006, 2007, 2008, 2009; Van Houtte and Verbauwhede, 2010; Clauwaert, oral communication; Van Houtte, oral communication). The CAS plant 'Wulpen' (1978) was designed to treat a biochemical oxygen demand (BOD) inhabitant equivalent of 74700 . Depicted flowrates represent the rounded yearly average over the period 2005-2009 in $\mathrm{Mm}^{3}$ year ${ }^{-1}$ (mmy). Subscripts 'el' and 'foss' refer to electrical and fossil fuel, respectively; UV: ultraviolet.

The four presented examples show that safe potable water reuse from a CAS effluent is technologically and economically feasible through a multiple barrier approach. Social acceptance can be obtained by good documentation, communication and interaction, although direct reuse could pose some psychological 
difficulties, especially in regions that are not under heavy water stress. Although the CAS approach with additional membrane technologies does not represent an optimal way to recover the other resources in the used water (Table 1), the add-on of MF/UF and RO in novel treatment schemes appears to pose no problems.

\section{ZeroWasteWater technologies for source-separated treatment}

Several options have been proposed for source separation at the household level of either yellow water (urine), brown water (faeces), black water (urine and faeces) and/or grey water (washing water from laundry, kitchen, shower and bath) (Otterpohl et al., 1999). An example of a yellow water separation device is the so-called No-Mix toilet, for which clever and safe urine treatment technologies have been conceived, which can also be applied in developing countries, involving sand-bed nitrification and solar evaporation, recovering substantial N and P amounts as fertilizer (Pronk and Koné, 2009).

Currently few source-separated schemes have a complete treatment train in operation. Yet, this approach can be feasible and profitable, as for instance shown in a pioneering project in Sneek (NL), where grey and concentrated black water is collected from 32 houses (Zeeman et al., 2008; Meulman et al., 2010). The integrated treatment approach allows maximum recovery of the resources in both water streams (Fig. 5). The black water vacuum collection system consumes $25 \mathrm{kWh}_{\mathrm{el}} \mathrm{IE}^{-1} \mathrm{year}^{-1}$ (Otterpohl et al., 1997), but it uses about seven times less water (only $1 \mathrm{~L}$ per flush). Additionally per flush some $100 \mathrm{~L}$ of air is consumed per flush, which is deodorized in a biofilter filled with wooden chips. The vacuum system hence gives a very concentrated black water stream which is directly suitable for anaerobic digestion in an upflow anaerobic sludge blanket (UASB), which is additionally fed with ground kitchen waste and sludge from the grey water treatment line, produced in a highly loaded activated sludge process concentrating the organics in the sludge. In the case of Sneek, a co-combustion unit is used which switches between biogas and natural gas to heat the connected houses. Following digestion, the majority of the nitrogen (and some residual carbon) is removed with minimal energy consumption by oxygen-limited autotrophic nitrification/denitrification (OLAND), which is a one-stage process combining partial nitritation and anammox (Vlaeminck et al., 2009b). Although OLAND is already 60\% more energy-efficient than nitrification/denitrification (Mulder, 2003), the energy-efficiency is further improved by applying passive aeration in a rotating biological contactor, instead of using direct bubble aeration. Subsequently, phosphorus is recovered with some residual ammonium as struvite $\left(\mathrm{MgNH}_{4} \mathrm{PO}_{4} \cdot 6 \mathrm{H}_{2} \mathrm{O}\right)$, a slow release fertilizer which also contains some nitrogen $\left(0.45 \mathrm{~g} \mathrm{~N} \mathrm{~g}^{-1} \mathrm{P}\right)$. Through the capturing of phosphorus in the sludge of the grey water line with a biological phosphorus removal step, a significant part of the excreted phosphorus can be recovered. The effluent of the black water line is returned to the grey water line for final polishing. After this, significant amounts of energy can be recovered from the effluent, given the year-average effluent temperature of $17.5^{\circ} \mathrm{C}$ (Meulman, oral communication). 


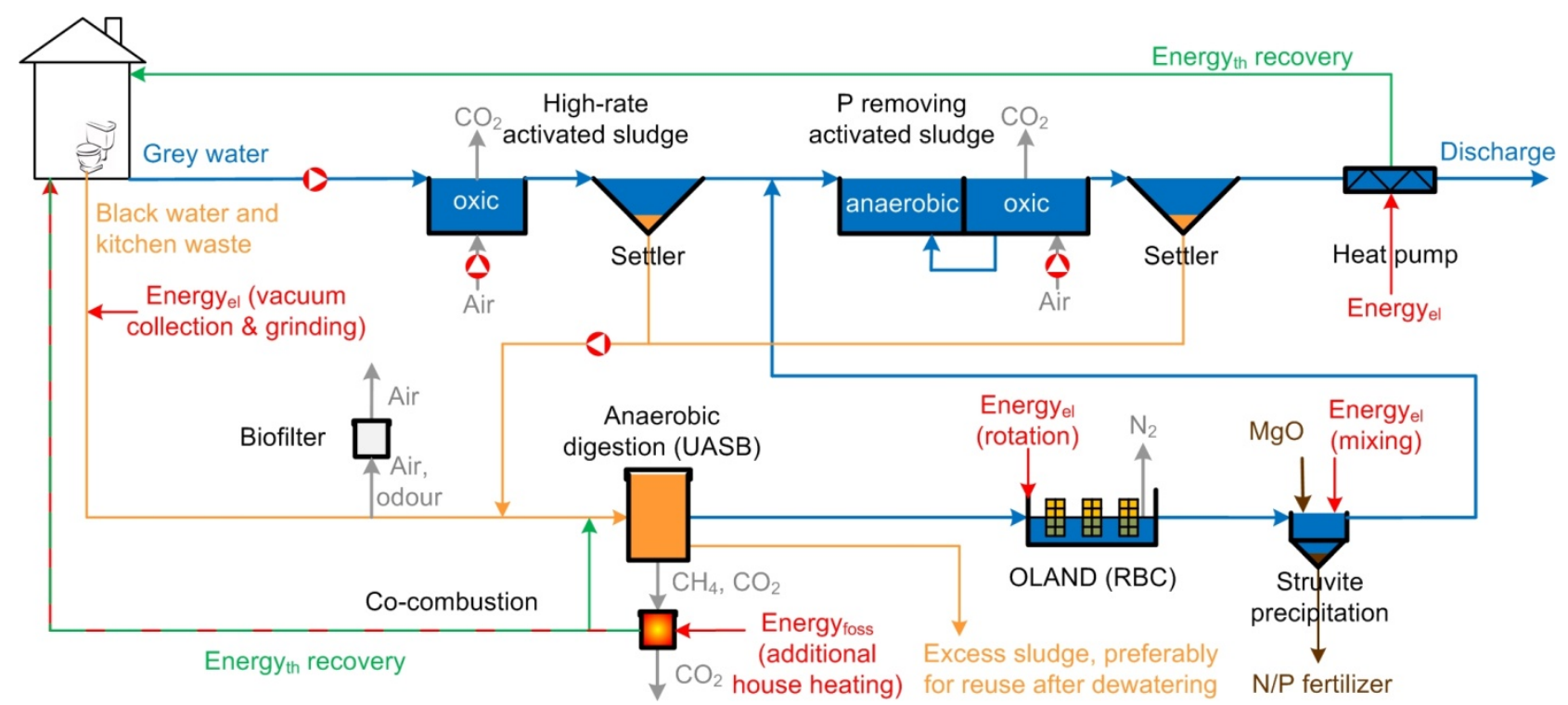

Figure 5. Scheme of source-separated sanitation implementing energy and nutrient recovery as practised for 32 houses in Sneek (the Netherlands), updated from Zeeman et al. (2008), Vlaeminck et al. (2009b), Meulman et al. (2010) and Meulman (oral communication). UASB: upflow anaerobic sludge blanket; OLAND: oxygen-limited autotrophic nitrification/denitrification; RBC: rotating biological contactor; Subscripts 'el', 'th' and 'foss' refer to electrical, thermal and fossil fuel, respectively

As a new source-separated concept, we propose to integrate the use of grey water and sunlight to establish a 'productive algal roof', exploiting already existing surface on houses. The roof can be used as a kind of flat panel photobioreactor to grow microalgae on the nutrients present in pre-treated grey water and $\mathrm{CO}_{2}$ from the atmosphere. Similar to the weekly collection of garbage, the algae can be harvested with a mobile centrifuge and subsequently transported to a centralized anaerobic digestion plant for energy recovery, as proposed by Zamalloa et al. (in press). In a rough approximation, assuming a $100 \mathrm{~m}^{2}$ roof and a productivity of $20 \mathrm{~g}$ dry matter $\mathrm{m}^{-2} \mathrm{~d}^{-1}$ (Eriksen, 2008), one family would produce around $810 \mathrm{~kg}$ COD year $^{-1}$, given an operational period of $300 \mathrm{~d} \mathrm{year}^{-1}$, an organic content of $90 \%$ and $1.5 \mathrm{~g} \mathrm{COD} \mathrm{g}^{-1}$ organics (Sialve et al., 2009). This biomass can be anaerobically fermented, converting $75 \%$ of the COD to biogas containing $75 \% \mathrm{CH}_{4}$, would yield a gross energy recovery of $866 \mathrm{kWh}_{\mathrm{el}}$ house $\mathrm{e}^{-1}$ year ${ }^{-1}$, as obtained using the energy conversion factors of Table 1 . For comparison, photovoltaic panels on roof tops produce in the order of $100 \mathrm{kWh}_{\mathrm{el} \mathrm{m}} \mathrm{m}^{-2}$ year ${ }^{-1}$, rendering a panel surface of $35-40 \mathrm{~m}^{2}$ sufficient to cover the average electricity consumption of Flemish family (VREG, 2010). Although the electricity production per roof surface is roughly one order of magnitude higher for photovoltaic panels compared to algal roofs, the latter might present a 'greener' overall approach of joint energy production and water treatment since it additionally allows to recycle grey water nutrients, take up atmospheric $\mathrm{CO}_{2}$, manage storm water, cool the house by heat transfer through the roof and recover energy relatively easy from the parallel black water line.

\section{ZeroWasteWater technologies for end-of-pipe treatment}

At the centralized level (order 100000 IE and higher), we propose an updated version of the out-of-the-box biorefinery design proposed by Verstraete et al. (2009). Firstly, a less diluted waste stream is prerequisite for energy and material recovery. A typical COD level of around $750 \mathrm{mg} \mathrm{COD} \mathrm{L}^{-1}$ could be expected based on the average household water consumption and COD load (Table 1). However, because of dilution with storm and infiltration water, this concentration is, in practice, much lower. In average German conditions for instance, the sewage is diluted with a factor 3.4 (Brombach et al., 2005), giving rise to about $225 \mathrm{mg} \mathrm{COD} \mathrm{L}{ }^{-1}$. For energy recovery from anaerobic digestion, considerably higher COD levels are desirable. In case the anaerobic digestor is heated only with the recovered thermal energy from a CHP unit, $5.4 \mathrm{~g} \mathrm{COD} \mathrm{L}^{-1}$ is required to heat sewage from 17 to $34^{\circ} \mathrm{C}$, as calculated from the energetic figures in 
Table 1. However, a significant part of the heat present in the digestate can be recovered and used to heat the influent of the digestor. To obtain higher COD levels, dilution and microbial activity in the sewer should be prevented, in addition to the use of an advanced concentrator upon entry at the new treatment facility (Fig. 6).

Sewage dilution can be prevented by a number of measures. Firstly, a separate sewer system with a sanitary and a storm sewer can increase pollutant concentrations by around $85 \%$, as calculated from typical German flow rates (Brombach et al., 2005). Secondly, infiltration in the sewer systems could be significantly decreased by improved maintenance. With $50 \%$ less infiltration, the concentrations will increase with only around $20 \%$ in combined sewer systems, but with around $140 \%$ in a separate sewer system (Brombach et al., 2005). Thirdly, in the latter system, water conservation of $25 \%$ could lead to a concentration increase of around $190 \%$. Such a decrease of the water use should be possible with relatively simple measures and ever increasing efficient water use of domestic applications. Finally, addition of ground kitchen waste can increase the COD concentration by around $70 \%$ (Table 1). Overall, these four abovementioned improvements could roughly increase the COD levels by a factor of 5 . An additional concentration possibility is the harvesting of irrigation water from the sewer, as proposed by Diamantis et al. (2010). In this concept, sewage is abstracted from the sewer, treated with primary membrane filtration (PMF) and the concentrated stream is returned to the sewer.

Microbial activity in the current sewer systems is not desirable since it leads to the formation of the greenhouse gas methane (Foley et al., 2009) and to hydrogen sulphide formation and the subsequent corrosion of sewers (Zhang et al., 2008). Furthermore, in the ZeroWasteWater concept, hydrolysis of particulate COD and consumption of dissolved COD should be minimal to obtain a maximum COD load to the treatment plant and a performant solid/liquid separation at the income of the plant. It takes hours to days for the sewerage microorganisms to bring all particulate components in the water into solution, the so-called liquefaction or hydrolysis. In 'fresh' black water for instance, only about $15 \%$ of the COD is soluble (Zeeman et al., 2008), whereas this is around 40-45\% when sewage reaches the CAS plant (Metcalf and Eddy, 2003; Henze, 2008). Furthermore, for long sewerage retention times, oxidation of 30\% of the dissolved COD was observed prior to arrival at the treatment plant (Huisman et al., 2004). Activated sludge models (ASM) can simulate COD fractionation and consumption in sewers (Zhou et al., 2008), and should be used to minimize these processes when (re)designing sewerage systems. In case around $50 \%$ of the hydrolysis and consumption can be prevented in the sewer, around 20\% more of the COD will reach the treatment plant, and about $15 \%$ more of the COD can be easily separated from the liquid. Additionally, this will lead to lower methane emissions and reduce the corrosion rate of the sewer. Faster transport can be achieved through the use of a vacuum or pressure system, rather than gravity, and through transportation over smaller distances (decentralizing and/or increase urbanization).

Clearly, upgrading existing sewage collection systems will be a very gradual process which can take several decades. However, the application of an advanced concentration step upon arrival of the sewage in the treatment plant can already be applied on the existing, diluted streams with levels of 225-750 mg COD $\mathrm{L}^{-1}$. At the entrance of the ZeroWasteWater plant, an advanced physicochemical or biological concentration step should divert $80 \%$ of the COD in less than $8 \%$ of the water, hence rendering a COD concentration of at least 10 times (Verstraete et al., 2009). Hence, even without prevention of dilution and microbial activity in the sewer, physicochemical techniques on current sewage should be able to obtain a digestible COD concentration. Appropriate concentration techniques include primary membrane filtration, dynamic sand filtration, dissolved air flotation, chemically enhanced primary sedimentation, biological sorption, poly-electrolyte dosage or a combination thereof. Of particular interest is biological sorption, or step A of the 'Adsorptions-Belebungsverfahren' or A/B process, in which a high sludge-specific loading rate is applied, yielding mainly conversion of organic carbon into microbial biomass (Boehnke et al., 1997). Anaerobic digestion of sludge produced with such high-rate activated sludge process, in 
combination with energy-friendly side stream nitrogen treatment has been shown to render energy selfsufficiency feasible at an Austrian wastewater treatment plant (Wett et al., 2007). Following the concentrator in the ZeroWasteWater scheme, biogas production can further be boosted by the addition of various organic waste streams, including algae and ground road clippings, expired food and restaurant waste (Fig. 6).

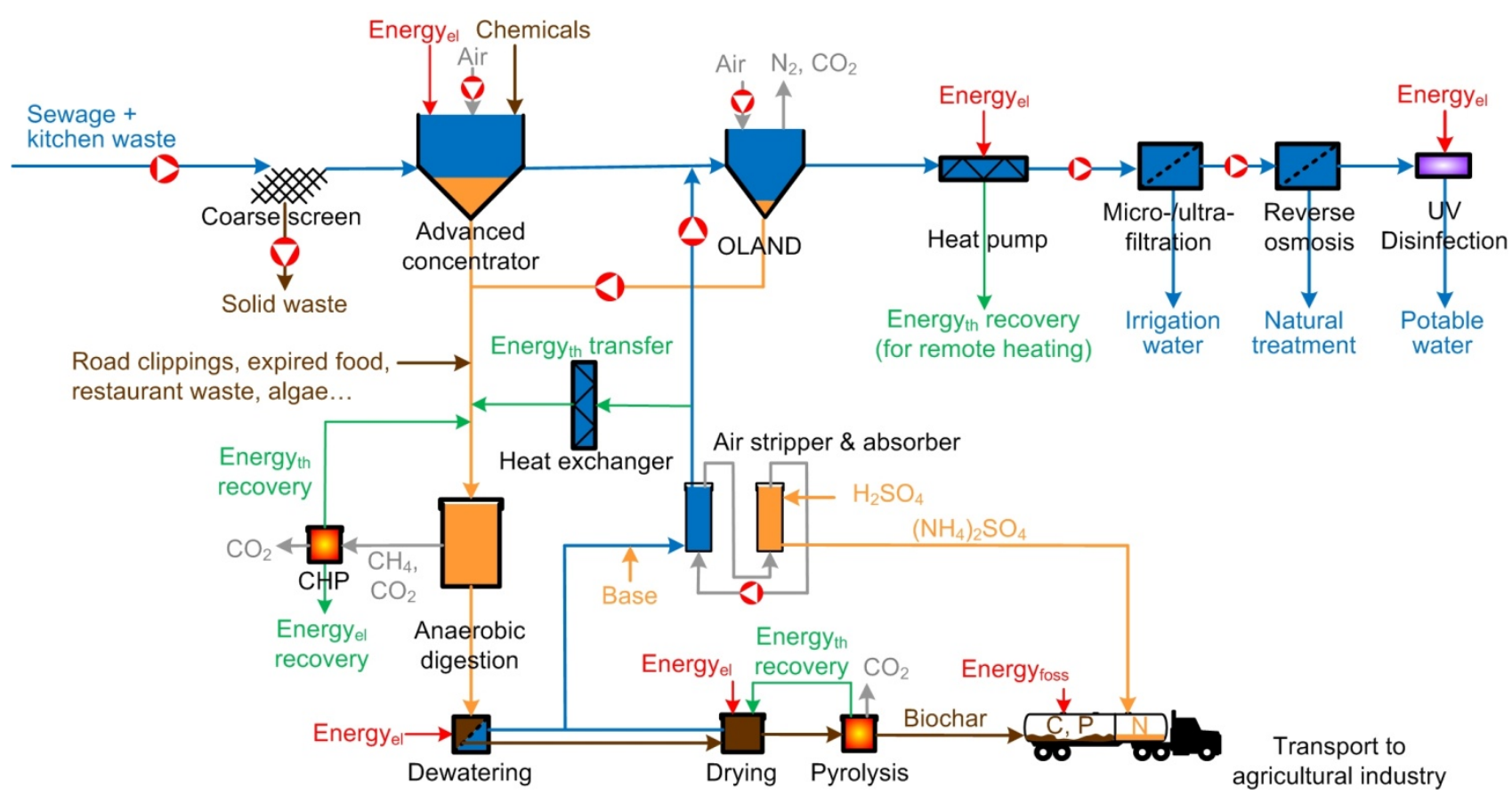

Figure 6. The centralized ZeroWasteWater approach, updated from Verstraete et al. (2009). Subscripts 'el', 'th' and 'foss' refer to electrical, thermal and fossil fuel, respectively; OLAND: oxygen-limited autotrophic nitrification/denitrification; UV: ultraviolet

The treatment train of the concentrate is primarily aimed at energy and materials recovery (Fig. 6). The electrical recovery from anaerobic digestion at mesophilic temperatures $\left(35^{\circ} \mathrm{C}\right)$ will be the second largest saving on the energy and $\mathrm{CO}_{2}$ balances (Table 2). For nitrogen stripping, aeration is required next to the addition of a base such as $\mathrm{CaO}$ to raise the $\mathrm{pH}$ and an acid such as $\mathrm{H}_{2} \mathrm{SO}_{4}$ to capture the ammonia in the stripped gas. In this way, a 40\% $\left(\mathrm{NH}_{4}\right)_{2} \mathrm{SO}_{4}$ solution can be obtained at $\mathrm{pH}<3.5$ (Siegrist, 1996). Although stripping imposes a higher electricity consumption, the fossil-fuel equivalent energy demand presents a decrease, since a considerable amount of heat is recovered from the production of $\mathrm{CaO}$ (Table 2). Furthermore, the increased use of electricity for stripping is compensated by the avoided energy for nitrogen removal through CAS and the lower energy demand to remove the residual nitrogen through OLAND (Table 2). Under realistic conditions, the remainder solid fraction might be enriched with undesirable trace organics. In order to prevent their re-entry into the environment, one can dewater and dry these solids, and finally pyrolyse them to biochar. Concerning heavy metals, careful origin tracing, monitoring and treatment if required should prevent their short-cycling in sewage sludge and hence biochar. Integration of biochar in the soil (up to 100 ton $\mathrm{C} \mathrm{ha}^{-1}$ ) not only represents an excellent and safe way to improve soil fertility, but also is one of the superior routes to sequester carbon and decrease carbon emission to the atmosphere (Lehmann, 2007). For ZeroWasteWater, biochar production reperesents the third largest source for avoided $\mathrm{CO}_{2}$ emissions (Table 2). Future experimental results should demonstrate that the phosphorus in the biochar is rendered bio-available under field conditions. If this is not the case, another phosphorus recovery pathway should be considered.

Following the concentrator, the water line will represent $90-95 \%$ of the volumetric flow, and will be subject to an aerobic polishing of residual $\mathrm{C}$ and N, heat recovery and an upgrade to potable water (Fig. 6). 
Since COD/N ratios will be relatively low $(\leq 2)$, the OLAND process can be used to oxidize the residual carbon and nitrogen. Indeed, OLAND has a low energy consumption and sludge production and does not require the addition of organic carbon, rendering the overall outcome not only 30-40\% less expensive than nitrification/denitrification (Fux and Siegrist, 2004), but also more sustainable. Although the OLAND technology has been mainly used for treatment of highly nitrogenous waste streams so far, this technology can also treat low nitrogen concentrations $\left(30-60 \mathrm{mg} \mathrm{N} \mathrm{L}^{-1}\right)$ at low hydraulic retention time $(1-2 \mathrm{~h})$ and high rates (400 $\mathrm{mg} \mathrm{N} \mathrm{L}^{-1} \mathrm{~d}^{-1}$ ) (De Clippeleir et al., in press). Besides high removal efficiencies, a high solids retention time and easy biomass retention are needed, rendering well-settling granular biomass as an appealing option (De Clippeleir et al., 2009; Vlaeminck et al., 2009a; Vlaeminck et al., 2010). Following OLAND, usable heat will be recovered with two sequential heat pumps, and this recovered energy represents about half of the fossil-fuel equivalent energy and of the $\mathrm{CO}_{2}$ footprint advantages of ZeroWasteWater compared to CAS (Table 2). The final upgrade to drinking water quality can be similar to the existing schemes as discussed above in Section 4: MF/UF ( $>85 \%$ recovery), RO ( $>75 \%$ recovery) and $\mathrm{UV}$, yielding overall around $60 \%$ of the original sewage flow.

In an overall estimation, the ZeroWasteWater approach allows to save $439 \mathrm{kWh} \mathrm{IE}^{-1}$ year ${ }^{-1}$ from fossil fuels compared to a CAS system without sludge digestion, and furthermore avoids an equivalent emission of $88 \mathrm{~kg} \mathrm{CO}_{2} \mathrm{IE}^{-1}$ year $^{-1}$ (Table 2). Since the add-on of membrane technologies to recover potable water would have comparable effects on the energy and $\mathrm{CO}_{2}$ balances of the CAS and ZeroWasteWater approach, this was not included in the calculations. With current operational emissions of CAS amount to an equivalent footprint of $80 \mathrm{~kg} \mathrm{CO}_{2} \mathrm{IE}^{-1}$ year ${ }^{-1}$, as mentioned above, this would render ZeroWasteWater carbon-neutral in its operation. Globally, $13.7 \times 10^{12} \mathrm{~kg} \mathrm{CO}_{2}$ year ${ }^{-1}$ is emitted from fossil fuel combustion (UNFCCC, 2008), or $1990 \mathrm{~kg} \mathrm{CO}_{2} \mathrm{IE}^{-1}$ year $^{-1}$ (6.9 billion IE). As such, ZeroWasteWater could prevent $4.4 \%$ of the global $\mathrm{CO}_{2}$ emissions. If we take the issue of decarbonising the global economy seriously and indeed strive for an $80 \%$ decrease in greenhouse gas emissions by 2050 , we will have to implement measures that will cost more than 100 EUR ton ${ }^{-1} \mathrm{CO}_{2}$ (IPCC, 2007). If such prices would effectively be payed for, ZeroWasteWater would present an additional economic gain of about $8.8 \mathrm{EUR} \mathrm{IE}^{-1}$ year $^{-1}$. Future analyses should confirm the figures of Table 2 experimentally, and further include figures from improved sewerage, separate storm water treatment, avoided costs for drinking water production from conventional natural water resources and life cycle analysis of all chemicals and materials involved. An economic estimation showed that the ZeroWasteWater concept is reasonable with a cost in the order of 1.0 EUR $\mathrm{m}^{-3}$ of water treated (Verstraete et al., 2009), which is in the same order of magnitude as CAS with the add-on technologies for potable water recovery. Both approaches share the recovery of potable water, valued at 1.2 EUR $\mathrm{m}^{-3}$ produced, so $0.8 \mathrm{EUR} \mathrm{m}^{-3}$ of wastewater treated (Table 1), but the ZeroWasteWater approach additionally recovers nutrients and biochar at an approximate market value of 6.3 EUR IE Eear $^{-1}$ or 0.07 EUR m$^{-3}$ of wastewater treated (Table 1). Future economic estimations should also include a cost/benefit analysis of sewerage improvements.

Table 2. Estimated potential energy gain and avoided $\mathrm{CO}_{2}$ emissions from the centralized ZeroWasteWater approach, compared to a conventional activated sludge (CAS) process without anaerobic sludge digestion. Fossil fuel equivalents were calculated at $0.31 \mathrm{kWh}$ electrical $\left(\mathrm{kWh}_{\mathrm{el}}\right)$ produced per $\mathrm{kWh}$ fossil fuel $\left(\mathrm{kWh}_{\text {foss }}\right)$ burned (Maurer et al., 2003) and $0.62 \mathrm{kWh}$ thermal $\left(\mathrm{kWh}_{\mathrm{th}}\right)$ produced per $\mathrm{kWh}_{\text {foss }}$ burned. Avoided $\mathrm{CO}_{2}$ emission from fossil fuels was calculated at $0.6 \mathrm{~kg} \mathrm{CO}_{2} \mathrm{kWh}_{\mathrm{el}}{ }^{-1}, 0.3 \mathrm{~kg} \mathrm{CO}_{2}$ $\mathrm{kWh}_{\mathrm{th}}{ }^{-1}$ and $0.25 \mathrm{~kg} \mathrm{CO} \mathrm{kWh}_{\text {foss }}{ }^{-1}$ of natural gas (Fruergaard et al., 2009). OLAND: oxygen-limited autotrophic nitrification/denitrification.

\begin{tabular}{|c|c|c|c|c|c|}
\hline & \multicolumn{4}{|c|}{ Energy gain $\left(\mathrm{kWh} \mathrm{IE}^{-1}\right.$ year $\left.^{-1}\right)$} & \multirow{2}{*}{$\begin{array}{c}\text { Avoided } \mathrm{CO}_{2} \text { emission } \\
\left(\mathrm{kg} \mathrm{CO}_{2} \mathrm{IE}^{-1} \text { year }^{-1}\right)\end{array}$} \\
\hline & Electricity & Heat & Fossil fuel & Fossil fuel equivalents & \\
\hline Kitchen grinder $^{\mathrm{a}}$ & -1.4 & & & -4.6 & -0.9 \\
\hline Advanced concentrator ${ }^{\mathrm{b}}$ & -6.0 & & & -19.4 & -3.6 \\
\hline OLAND $^{c}$ & 12.8 & & & 35.5 & 6.6 \\
\hline Heat recovery $^{a}$ & -179 & 496 & & 222.6 & 41.7 \\
\hline Anaerobic digestion $^{a}$ & 38.9 & & & 125.4 & 23.3 \\
\hline Sludge dewatering $^{\mathrm{d}}$ & 1.8 & & & 5.8 & 1.1 \\
\hline $\mathrm{N}$ recovery ${ }^{\mathrm{e}}$ & -9.6 & 40.8 & 22.5 & 57.5 & $12.3-8.8^{\mathrm{h}}$ \\
\hline
\end{tabular}




\begin{tabular}{l|cccc|c}
$\begin{array}{l}\text { P recovery } \\
\text { Biochar }^{\mathrm{g}}\end{array}$ & 1.2 & & 5.0 & 8.7 & 2.0 \\
\hline Sum & & & & & 13.3 \\
\hline
\end{tabular}

${ }^{\text {a }}$ See text or Table 1

${ }^{\mathrm{b}}$ Estimated for a chemically enhanced biosorption step, separating the particulate chemical oxygen demand (COD), which constitutes $70 \%$ of the overall COD, and $50 \%$ of the dissolved COD as activated sludge produced at high rate. The latter represents a stream of $12 \mathrm{~kg} \mathrm{COD} \mathrm{IE}^{-1}$ year $^{-1}$ with the values of Table 1 . High-rate activated sludge consumes $0.11 \mathrm{kWh}_{\mathrm{el}} \mathrm{kg}^{-1}$ COD total removed (DBW/RIZA and Stora, 1991), which at the particulate COD content of regular sewage $(57.5 \%)$ approximates $0.25 \mathrm{kWh}_{\mathrm{el}} \mathrm{kg}^{-1} \mathrm{COD}$ dissolved.

${ }^{\mathrm{c}}$ This stage receives $15 \%$ of the COD load and $50 \%$ of the $\mathrm{N}$ load, and is assumed to remove 95 and $80 \%$ of the COD and $\mathrm{N}$, respectively, hence converting 11 and $2.0 \mathrm{~kg} \mathrm{IE}^{-1} \mathrm{year}^{-1}$ of COD and $\mathrm{N}$, respectively (Table 1). At the same sewage load as in Table 1, a regular CAS oxidizes around 19 and $4 \mathrm{~kg} \mathrm{IE}^{-1}$ year $^{-1}$ of COD and N, respectively, biologically (Siegrist et al., 2008). At an aeration efficiency of $2 \mathrm{~kg} \mathrm{O}_{2} \mathrm{kWh}_{\mathrm{el}}{ }^{-1}$, COD oxidation requires $0.5 \mathrm{kWh}_{\mathrm{el}} \mathrm{kg}^{-1} \mathrm{COD}$, assuming an oxygen requirement of $1 \mathrm{~kg} \mathrm{O}_{2} \mathrm{~kg}^{-1}$ COD removed, and nitrogen oxidation requires 2.3 or $0.9 \mathrm{kWh}_{\mathrm{el}} \mathrm{kg}^{-1} \mathrm{~N}$, for nitrification/denitrification or OLAND, respectively (Mulder, 2003). Furthermore, a decrease of $25 \%$ of the pumping energy is assumed since the recirculation streams for denitrification are not necessary (Kartal et al., 2010). As such, compared to CAS, ZeroWasteWater saves 3.8, 7.2 and $1.8 \mathrm{kWh}_{\mathrm{el}} \mathrm{IE}^{-1}$ year $^{-1}$ for $\mathrm{C}$ aeration, $\mathrm{N}$ aeration and pumping, respectively.

${ }^{\mathrm{d}}$ Dewatering requires $0.16 \mathrm{kWh} \mathrm{kg}^{-1}$ dry matter (Zessner et al., 2010), which is around $0.15 \mathrm{kWh} \mathrm{kg}^{-1} \mathrm{COD}$ assuming $70 \%$ volatile solids (VS) in the sludge dry matter and $1.5 \mathrm{~g} \mathrm{COD} \mathrm{g}^{-1}$ VS. At the same sewage load of Table 1, a CAS plant would produce sludge at $31 \mathrm{~kg} \mathrm{COD} \mathrm{IE}^{-1}$ year $^{-1}$ (Siegrist et al., 2008), whereas this is $19 \mathrm{~kg} \mathrm{COD} \mathrm{IE}^{-1}$ year $^{-1}$ in the ZeroWasteWater concept (Table 1).

${ }^{\mathrm{e}}$ Recovery of half of the nitrogen load represents $2.55 \mathrm{~kg} \mathrm{~N} \mathrm{IE}^{-1} \mathrm{year}^{-1}$ (Table 1). Although the current nitrogen content in sludge reject water is up to 0.8-1.2 $\mathrm{g} \mathrm{N} \mathrm{L}^{-1}$ (Johansson et al., 1998; Nyhuis et al., 2006; Jeanningros et al., 2010), the digestion of more concentrated streams should lead to $2.0 \mathrm{~g} \mathrm{~N} \mathrm{~L}^{-1}$ in the reject water, requiring an aeration at $7 \mathrm{kWh}_{\mathrm{el}} \mathrm{m}^{-3}$ (Siegrist, 1996), and addition of $9.6 \mathrm{~kg} \mathrm{H}_{2} \mathrm{SO}_{4} \mathrm{~kg}^{-1} \mathrm{~N}$ and $2.4 \mathrm{~kg} \mathrm{CaO} \mathrm{kg}^{-1} \mathrm{~N}$ (Siegrist, 1996). Per kg of CaO produced from $\mathrm{CaCO}_{3}, 1.18$ $\mathrm{kWh}_{\text {foss }}$ and $0.03 \mathrm{kWh}_{\mathrm{el}}$ are required (IPPC, 2001). Per kg of $\mathrm{H}_{2} \mathrm{SO}_{4}$ produced, $0.04 \mathrm{kWh}_{\mathrm{el}}$ is consumed but also $1.67 \mathrm{kWh}_{\mathrm{th}}$ is recovered (IPPC, 2007). By recovering nitrogen, less has to be produced through the Haber-Bosch process. Under European conditions, the production of ammonia requires $9.5 \mathrm{kWh}_{\text {foss }}$ of natural gas kg $\mathrm{kg}^{-1} \mathrm{~N}$ and further conversion to urea requires an additional $2.2 \mathrm{kWh} \mathrm{kg}^{-1} \mathrm{~N}$ of natural gas and $0.24 \mathrm{kWh}_{\mathrm{el}} \mathrm{kg}^{-1} \mathrm{~N}$ (IPPC, 2007).

${ }^{\mathrm{f}} \mathrm{Per} \mathrm{kg}$ of $\mathrm{CaO}$ produced from $\mathrm{CaCO}_{3}, 0.78 \mathrm{~kg} \mathrm{CO}$ is released (IPPC, 2001) and the partly avoided production of urea sequesters $1.57 \mathrm{~kg} \mathrm{CO}_{2} \mathrm{~kg}^{-1} \mathrm{~N}$ less (IPPC, 2007).

${ }^{\mathrm{g}}$ Energy saved from avoided P fertilizer production, using average European data (Maurer et al., 2003) and the recovery of 0.92 $\mathrm{kg} \mathrm{P} \mathrm{IE}^{-1}$ year $^{-1}$ (Table 1$)$.

\section{Sustainable cities of the future: the barrier is all in the mind}

Although CAS succeeds in reaching sufficiently low COD, $\mathrm{N}$ and $\mathrm{P}$ effluent levels, it is costly, and requires a high fossil fuel consumption and $\mathrm{CO}_{2}$ footprint. Projected water and phosphorus shortages and the need to lower greenhouse gas emissions force us to rethink wastewater treatment for sustainable cities of the future. ZeroWasteWater offers an approach to short-cycle water, energy and valuable materials while adequately abating pathogens, heavy metals and trace organics. A less diluted waste stream will be obtained from sewerage improvements, a more rational use of potable water and the addition of ground kitchen waste, complemented by an advanced physicochemical or/and biological concentration step at the entry of the sewage treatment plant. Further key technologies include anaerobic digestion, air stripping and pyrolysis for the concentrated stream and OLAND, heat pumps and membrane technologies for the water stream. Interestingly, ZeroWasteWater is expected to recover significant amounts of products while being economically viable and presenting a lower fossil fuel demand and $\mathrm{CO}_{2}$ emission.

Public acceptance is pivotal when designing the cities of the future according to the ZeroWasteWater concept. Sanitation remains taboo for many cultures, religions and in some cases even science... We should not underestimate the force of particular views which are non-compatible with the paradigm of sanitation by implementing the cradle to cradle concept, especially for potable purposes. It will take decades of education and demonstration to convince people that recycling and health can go together as part of a sustainable bioeconomy. In this respect, there might be a need to give thorough consideration to the question of whether or not a novel technology or scheme can be acceptable, taking into account not 
only our western lines of thinking, but the global cultural boundaries in terms of sanitation. The source separation approach of a No-Mix toilet was for instance found to be acceptable to all cultures and religions (Lienert and Larsen, 2010). Besides the public acceptance, research incentives are crucial to move towards a sustainable and safe future, and to interest scientists in designing conceptually sound sanitation to make the world much more safe and sustainable for the future. Overall, there is an urgent need for a genuine interest in a new, cradle to cradle approach for the urban water chain. We must all convince the coming generation of urban planners of the value of culturally acceptable and sound sanitation by means of new integrated technologies.

\section{Acknowledgements}

This work was supported by a postdoctoral fellowship from the Research Foundation Flanders (FWOVlaanderen) for S.E.V. and by SewagePlus II, an Interdisciplinary Cooperative Research project financed by the Flemish Environmental and Energy Technology Innovation Platform (MIP-ICON) and the Institute for the Promotion of Innovation by Science and Technology in Flanders (IWT-Vlaanderen). The authors gratefully thank Emmanuel Van Houtte (IWVA, B), Peter Clauwaert (Aquafin, B) and Brendo Meulman (Landustrie, NL) for their contribution to figures 4 and 5, respectively, Hans Mollen (Waterschap Brabantse Delta, NL) for sharing temperature data and Regine Haspeslagh, Carlos Zamalloa, Bert Bundervoet, Bram Eggermont, Irene Nansubuga, Suzanne Read, Arnout D’Haese, Joachim Desloover, Bart De Gusseme, Sebastià Puig and Dennis Cardoen for carefully reading and editing of this manuscript.

\section{References}

Alcamo, J., Florke, M., and Marker, M. (2007) Future long-term changes in global water resources driven by socio-economic and climatic changes. Hydrological Sciences Journal-Journal Des Sciences Hydrologiques 52: 247-275.

Apodaca, L.E. (2010) Nitrogen. In 2008 Minerals Yearbook. Reston: U.S. Department of the Interior, U.S. Geological Survey, pp. 53.51-53.17.

Belgian Science Policy (2009) Huishoudens en gezinnen in België (Households and families in Belgium). Belgian Science Policy and Federal Public Service of Economy, S.M.E.s, Self-employed and Energy.

Boehnke, B., Diering, B., and Zuckut, S.W. (1997) Cost-effective wastewater treatment process for removal of organics and nutrients. Water-Engineering \& Management 144: 18-21.

Bolong, N., Ismail, A.F., Salim, M.R., and Matsuura, T. (2009) A review of the effects of emerging contaminants in wastewater and options for their removal. Desalination 239: 229-246.

Brombach, H., Weiss, G., and Fuchs, S. (2005) A new database on urban runoff pollution: comparison of separate and combined sewer systems. Water Sci. Technol. 51: 119-128.

Clauwaert, P., Roels, J., Thoeye, C., De Gueldre, G., and Van De Steene, B. (2010) Evaluatie van de milieuimpact van rioolafvalwaterzuivering met nutriëntenverwijdering met behulp van levenscyclusanalyse (LCA) (Evaluation of the environmental impact of sewage treatment with nutrient removal by means of life cycle analysis (LCA)). WT-Afvalwater 10: 186-195.

Cordell, D., Drangert, J.O., and White, S. (2009) The story of phosphorus: Global food security and food for thought. Global Environmental Change-Human and Policy Dimensions 19: 292-305.

Cornel, P., and Schaum, C. (2009) Phosphorus recovery from wastewater: needs, technologies and costs. Water Sci. Technol. 59: 1069-1076.

Dailey, S.V., Mahoney, K., Bradley, N.S., Pitt, P.A., and Smith, R.D. (2010) The development of the New York City BNR program. In IWA World Water Congress \& Exhibition. Montréal, Canada.

DBW/RIZA, and Stora (1991) AB-systemen: een inventarisatie (AB systems: an inventory). Rijksinstituut voor Integraal Zoetwaterbeheer en Afvalwaterbehandeling Dienst Binnenwateren and Stichting toegepast onderzoek reiniging afvalwater, Lelystad.

De Clippeleir, H., Vlaeminck, S.E., Carballa, M., and Verstraete, W. (2009) A low volumetric exchange ratio allows high autotrophic nitrogen removal in a sequencing batch reactor. Bioresour. Technol. 100: 5010-5015. 
De Clippeleir, H., Yan, X., Desloover, J., Verstraete, W., and Vlaeminck, S.E. (in press) OLAND is feasible to treat sewage-like nitrogen concentrations at low hydraulic residence time. In WEF-IWA Nutrient recovery and management: Inside and outside the fence. Miami, the United States.

Dewettinck, T., Van Houtte, E., Geenens, D., Van Hege, K., and Verstraete, W. (2001) HACCP (Hazard Analysis and Critical Control Points) to guarantee safe water reuse and drinking water production - a case study. Water Sci. Technol. 43: 31-38.

Diamantis, V.I., Leontaridou, A., Antoniou, I., Melidis, P., and Aivasidis, A. (2010) Water recovery from sewers: Sewer Water Abstraction Plant (SWAP) technology for decentralized applications (in Greek). In Third Conference on Small Decentralized Water and Wastewater Treatment Plants. Skiathos, Greece.

du Pisani, P.L. (2006) Direct reclamation of potable water at Windhoek's Goreangab reclamation plant. Desalination 188: 79-88.

Durham, B., Bourbigot, M.M., and Pankratz, T. (2001) Membranes as pretreatment to desalination in wastewater reuse: operating experience in the municipal and industrial sectors. Desalination 138: 83-90.

Eandis (2007) Eandismagazine - wegwijs in energie (guide to energy).

Elmitwalli, T.A., and Otterpohl, R. (2007) Anaerobic biodegradability and treatment of grey water in upflow anaerobic sludge blanket (UASB) reactor. Water Res. 41: 1379-1387.

Eriksen, N.T. (2008) The technology of microalgal culturing. Biotechnol. Lett. 30: 1525-1536.

Europe's Energy Portal (2010). Feed-in Tariffs. URL http://www.energy.eu/\#feedin. Accessed 2010/11/16.

Foley, J., Yuan, Z.G., and Lant, P. (2009) Dissolved methane in rising main sewer systems: field measurements and simple model development for estimating greenhouse gas emissions. Water Sci. Technol. 60: 2963-2971.

Fongsatitkul, P., Wareham, D.G., and Elefsiniotis, P. (2008) The influence of organic loading and anoxic/oxic times on the removal of carbon, nitrogen and phosphorus from a wastewater treated in a sequencing batch reactor. Journal of Environmental Science and Health Part a-Toxic/Hazardous Substances \& Environmental Engineering 43: 725-730.

Fruergaard, T., Astrup, T., and Ekvall, T. (2009) Energy use and recovery in waste management and implications for accounting of greenhouse gases and global warming contributions. Waste Manag. Res. 27: 724-737.

Fux, C., and Siegrist, H. (2004) Nitrogen removal from sludge digester liquids by nitrification/denitrification or partial nitritation/anammox: environmental and economical considerations. Water Sci. Technol. 50: 19-26.

Galloway, J.N., Townsend, A.R., Erisman, J.W., Bekunda, M., Cai, Z.C., Freney, J.R. et al. (2008) Transformation of the nitrogen cycle: Recent trends, questions, and potential solutions. Science 320: 889892.

Haarhoff, J., and Van der Merwe, B. (1996) Twenty-five years of wastewater reclamation in Windhoek, Namibia. Water Sci. Technol. 33: 25-35.

Henze, M. (1997) Waste design for households with respect to water, organics and nutrients. Water Sci. Technol. 35: 113-120.

Henze, M. (2008) Wastewater characterization. London: IWA Publishing.

Hernandez Leal, L., Temmink, H., Zeeman, G., and Buisman, C.J.N. (2010) Bioflocculation of grey water for improved energy recovery within decentralized sanitation concepts. Bioresour. Technol. 101: 90659070.

Huisman, J.L., Gasser, T., Gienal, C., Kuhni, M., Krebs, P., and Gujer, W. (2004) Quantification of oxygen fluxes in a long gravity sewer. Water Res. 38: 1237-1247.

IPCC (2007) Climate Change 2007: Mitigation of Climate Change. Cambridge: Cambridge University Press.

IPPC (2001) Reference document on best available techniques in the cement and lime manufacturing industries. European Commission, Integrated Pollution Prevention and Control, Brussels. 
IPPC (2007) Reference document on best available techniques for the manufacture of large volume inorganic chemicals - ammonia, acids and fertilisers. European Commission, Integrated Pollution Prevention and Control, Brussels.

Isaacs, S.H., and Henze, M. (1995) Controlled carbon source addition to an alternating nitrificationdenitrification wastewater treatment process including biological P removal. Water Res. 29: 77-89.

IWVA (2005) Jaarverslag 2005 (Annual report 2005). Intercommunale Waterleidingsmaatschappij van Veurne-Ambacht (IWVA), Koksijde.

IWVA (2006) Jaarverslag 2006 (Annual report 2006). Intercommunale Waterleidingsmaatschappij van Veurne-Ambacht (IWVA), Koksijde.

IWVA (2007) Jaarverslag 2007 (Annual report 2007). Intercommunale Waterleidingsmaatschappij van Veurne-Ambacht (IWVA), Koksijde.

IWVA (2008) Jaarverslag 2008 (Annual report 2008). Intercommunale Waterleidingsmaatschappij van Veurne-Ambacht (IWVA), Koksijde.

IWVA (2009) Jaarverslag 2009 (Annual report 2009). Intercommunale Waterleidingsmaatschappij van Veurne-Ambacht (IWVA), Koksijde.

Jeanningros, Y., Vlaeminck, S.E., Kaldate, A., Verstraete, W., and Graveleau, L. (2010) Fast start-up of a pilot-scale deammonification sequencing batch reactor from an activated sludge inoculum. Water Sci. Technol. 61: 1393-1400.

Johansson, P., Nyberg, A., Beier, M., Hippen, A., Seyfried, C.F., and Rosenwinkel, K.-H. (1998) Cost efficient sludge liquor treatment. Joint Polish-Swedish Reports, Report No 3. Royal Institute of Technology, Stockholm, TRITA-AMI Report 3048.

Karlberg, T., and Norm, E. (1999) Food waste disposers - Effects on wastewater treatment plants, a study from the town of Surahammar. VA-FORSK, Stockholm.

Kartal, B., Kuenen, J.G., and van Loosdrecht, M.C.M. (2010) Sewage Treatment with Anammox. Science 328: $702-703$.

Kruse, H. (1962) Some present-day sewage-treatment methods in use for small communities in the Federal Republic of Germany. Bull. W.H.O 26: 542-549.

Kujawa-Roeleveld, K., Fernandes, T., Wiryawan, Y., Tawfik, A., Visser, W., and Zeeman, G. (2005) Performance of UASB septic tank for treatment of concentrated black water within DESAR concept. Water Sci. Technol. 52: 307-313.

Kurniawan, T.A., Chan, G.Y.S., Lo, W.H., and Babel, S. (2006) Physico-chemical treatment techniques for wastewater laden with heavy metals. Chem. Eng. J. 118: 83-98.

Lahnsteiner, J., and Lempert, G. (2007) Water management in Windhoek, Namibia. Water Sci. Technol. 55: 441-448.

Lantz, M., Svensson, M., Bjornsson, L., and Borjesson, P. (2007) The prospects for an expansion of biogas systems in Sweden - Incentives, barriers and potentials. Energy Policy 35: 1830-1843.

Lehmann, J. (2007) A handful of carbon. Nature 447: 143-144.

Levantesi, C., La Mantia, R., Masciopinto, C., Bockelmann, U., Ayuso-Gabella, M.N., Salgot, M. et al. (2010) Quantification of pathogenic microorganisms and microbial indicators in three wastewater reclamation and managed aquifer recharge facilities in Europe. Sci. Total Environ. 408: 4923-4930.

LFUW (2001) Energieoptimierung von Kläranlagen - Detailuntersuchung von 21 Anlagen (Energy optimisation in wastewater treatment plants - Detailed study of 21 plants). Bundesministerium für Landund Forstwirtschaft Umwelt und Wasserwirtschaft (LFUW).

Lienert, J., and Larsen, T.A. (2010) High Acceptance of Urine Source Separation in Seven European Countries: A Review. Environ. Sci. Technol. 44: 556-566.

Lua, A.C., Yang, T., and Guo, J. (2004) Effects of pyrolysis conditions on the properties of activated carbons prepared from pistachio-nut shells. Journal of Analytical and Applied Pyrolysis 72: 279-287.

Maurer, M., Schwegler, P., and Larsen, T.A. (2003) Nutrients in urine: energetic aspects of removal and recovery. Water Sci. Technol. 48: 37-46.

Metcalf, and Eddy (2003) Wastewater engineering, treatment and reuse. New York: McGraw-Hill. 
Meulman, B., Elzinga, N., Gorter, K., Zeeman, G., Buisman, C.J.N., Vlaeminck, S.E., and Verstraete, W. (2010) Pilot-scale demonstration of sustainable $\mathrm{C}$ and $\mathrm{N}$ removal from concentrated black water. In IWA World Water Congress \& Exhibition. Montréal, Canada.

Milieu, WRc, and RPA (2008) Environmental, economic and social impacts of the use of sewage sludge on land - Final report - Part I: Overview report (report prepared for the European Commission, DG Environment).

Mulder, A. (2003) The quest for sustainable nitrogen removal technologies. Water Sci. Technol. 48: 67-75. Müller, E.A., and Kobel, B. (2004) Energetische Bestandsaufnahme an Klärlanlagen in NordrheinWestfalen mit 30 Millionen Einwohnerwerten - Energie-Benchmarking und Sparpotenziale (Energy balances from wastewater treatment plants in Nordrhein-Westfalen with 30 million inhabitant equivalents - Energy benchmarking and saving potentials). Korrespondenz Abwasser 51: 625-631.

Murphy, J.D., McKeogh, E., and Kiely, G. (2004) Technical/economic/environmentaI analysis of biogas utilisation. Applied Energy 77: 407-427.

Nyhuis, G., Stadler, V., and Wett, B. (2006) Inbetriebnahme der ersten DEMON-Anlage in der Schweiz zur direkten Stickstoffelimination und erste Betriebsergebnisse (Taking into operation the first DEMON installation in Switzerland for direct nitrogen removal and first process results). In 6. Aachener Tagung mit Informationsforum: Stickstoffrückbelastung - Stand der Technik 2006. Grömping, M. (ed). Aachen, Germany: ATEMIS GmbH.

OCWD (2009) Orange County Water District - Groundwater management plan - 2009 update.

Otterpohl, R., Grottker, M., and Lange, J. (1997) Sustainable water and waste management in urban areas. Water Sci. Technol. 35: 121-133.

Otterpohl, R., Albold, A., and Oldenburg, M. (1999) Source control in urban sanitation and waste management: Ten systems with reuse of resources. Water Sci. Technol. 39: 153-160.

Pronk, W., and Koné, D. (2009) Options for urine treatment in developing countries. Desalination 248: 360-368.

PUB (2010). Public Utilities Board - NEWater. URL http://www.pub.gov.sg/water/Pages/NEWater.aspx. Accessed 2010/10/28.

Sialve, B., Bernet, N., and Bernard, O. (2009) Anaerobic digestion of microalgae as a necessary step to make microalgal biodiesel sustainable. Biotechnol. Adv. 27: 409-416.

Siegrist, H. (1996) Nitrogen removal from digester supernatant - Comparison of chemical and biological methods. Water Sci. Technol. 34: 399-406.

Siegrist, H., Salzgeber, D., Eugster, J., and Joss, A. (2008) Anammox brings WWTP closer to energy autarky due to increased biogas production and reduced aeration energy for N-removal. Water Sci. Technol. 57: 383-388.

Sorme, L., and Lagerkvist, R. (2002) Sources of heavy metals in urban wastewater in Stockholm. Sci. Total Environ. 298: 131-145.

Suh, Y.J., and Rousseaux, P. (2002) An LCA of alternative wastewater sludge treatment scenarios. Resour. Conserv. Recycl. 35: 191-200.

The World Bank (2010). Commodity Price Data (Pink Sheet). URL http://siteresources.worldbank.org/INTDAILYPROSPECTS/Resources/Pnk 1110.pdf. $\quad$ Accessed 2010/11/16.

Thornberg, D.E., and Johansen, N.B. (2010) Heat recovery from wastewater effluent. In IWA World Water Congress \& Exhibition. Montréal, Canada.

Tsagarakis, K.P., Mara, D.D., and Angelakis, A.N. (2003) Application of cost criteria for selection of municipal wastewater treatment systems. Water Air Soil Pollut. 142: 187-210.

UN (2010) The millennium development goals report. New York: United Nations.

UNEP (2004) Freshwater in Europe - Facts, Figures and Maps. Division of Early Warning and Assessment Office for Europe (DEWA-Europe) of the United Nations Environment Programme (UNEP), Geneva. 
UNEP, and UN-HABITAT (2010) Sick water? The central role of wastewater management in sustainable development. A rapid response assessment. United Nations Environment Programme (UNEP), UNHABITAT, GRID-Arendal, Arendal.
UNFCCC
(2008).
Greenhouse
Gas Inventory
Data.
URL

http://unfccc.int/di/DetailedByParty/Event.do?event=go. Accessed 2010/11/29.

Van Houtte, E., and Verbauwhede, J. (2008) Operational experience with indirect potable reuse at the Flemish Coast. Desalination 218: 198-207.

Van Houtte, E., and Verbauwhede, J. (2010) Long time membrane experience at Torreele's water re-use facility in Belgium. In Membranes in Drinking and Industrial Water Treatment (MDIW). Trondheim, Norway.

Verstraete, W., de Caveye, P.V., and Diamantis, V. (2009) Maximum use of resources present in domestic "used water". Bioresour. Technol. 100: 5537-5545.

Vlaeminck, S.E., Cloetens, L.F.F., Carballa, M., Boon, N., and Verstraete, W. (2009a) Granular biomass capable of partial nitritation and anammox (vol 58, pg 1113, 2008). Water Sci. Technol. 59: 609-617.

Vlaeminck, S.E., Terada, A., Smets, B.F., Van der Linden, D., Boon, N., Verstraete, W., and Carballa, M. (2009b) Nitrogen Removal from Digested Black Water by One-Stage Partial Nitritation and Anammox. Environ. Sci. Technol. 43: 5035-5041.

Vlaeminck, S.E., Terada, A., Smets, B.F., De Clippeleir, H., Schaubroeck, T., Bolca, S. et al. (2010) Aggregate size and architecture determine microbial activity balance for one-stage partial nitritation and anammox. Appl. Environ. Microbiol. 76: 900-909.

VREG (2010). Opbrengst zonnepanelen (Efficiency photovoltaic panels). URL http://www.vreg.be/nl/zonnepanelen/kleine\%20installaties/03 opbrengstzonnepanelen.asp. . Accessed 2010/11/23.

Wanner, O. (2009) Wärmerückgewinnung aus Abwasser: Wärmetauscherverschmutzung - Auswirkungen und Gegenmassnahmen (Heat recovery from wastewater: heat exchanger fouling - Results and countermeasures). Schriftenreihe der Eawag Nr. 19.

Wanner, O., Panagiotidis, V., Clavadetscher, P., and Siegrist, H. (2005) Effect of heat recovery from raw wastewater on nitrification and nitrogen removal in activated sludge plants. Water Res. 39: 4725-4734.

Wett, B., Buchauer, K., and Fimml, C. (2007) Energy self-sufficiency as a feasible concept for wastewater treatment systems. In IWA Leading Edge Technology Conference. Singapore.

WHO-UNICEF (2010) Progress on sanitation and drinking-water - 2010 update. Geneva - New York: World Health Organization - UNICEF.

WHO (2007). World Health Organization Global Health Atlas. URL http://apps.who.int/globalatlas/. Accessed 2010/10/12.

Zamalloa, C., Vulsteke, E., Albrecht, J., and Verstraete, W. (in press) The techno-economic potential of renewable energy through the anaerobic digestion of microalgae. Bioresour. Technol.: doi:10.1016/j.biortech.2010.1009.1017.

Zeeman, G., Kujawa, K., de Mes, T., Hernandez, L., de Graaff, M., Abu-Ghunmi, L. et al. (2008) Anaerobic treatment as a core technology for energy, nutrients and water recovery from source-separated domestic waste(water). Water Sci. Technol. 57: 1207-1212.

Zessner, M., Lampert, C., Kroiss, H., and Lindtner, S. (2010) Cost comparison of wastewater in Danubian countries. Water Sci. Technol. 62: 223-230.

Zhang, L., De Schryver, P., De Gusseme, B., De Muynck, W., Boon, N., and Verstraete, W. (2008) Chemical and biological technologies for hydrogen sulfide emission control in sewer systems: A review. Water Res. 42: 1-12.

Zhou, Z., Wu, Z.C., Wang, Z.W., Tang, S.J., and Gu, G.W. (2008) COD fractionation and parameter estimation for combined sewers by respirometric tests. J. Chem. Technol. Biotechnol. 83: 1596-1601. 